\title{
Extraction Methods, Characterization and Biomedical Applications of Collagen: a Review
}

\author{
Omar El Blidi ${ }^{1}$, Nasreddine El Omari ${ }^{1}$ (D), Abdelaali Balahbib ${ }^{2}$ (D), Rokia Ghchime ${ }^{3}$, Naoual El \\ Menyiy 4(i), Azeddine Ibrahimi 5(i), Khalid Ben Kaddour 1, Abdelhakim Bouyahya 6,*iD, Omar \\ Chokairi ${ }^{1}$, Malika Barkiyou ${ }^{1}$
}

1 Laboratory of Histology, Embryology, and Cytogenetic, Faculty of Medicine and Pharmacy, Mohammed V University in Rabat, Morocco

2 Laboratory of Biodiversity, Ecology, and Genome, Faculty of Sciences, Mohammed V University in Rabat, Morocco

3 Department of Clinical Neurophysiology, Hospital of Specialities, Ibn Sina University Hospital, Rabat Institute, Morocco

4 Laboratory of Physiology, Pharmacology \& Environmental Health, Faculty of Science, University Sidi Mohamed Ben Abdellah, Fez, Morocco

5 Laboratory of Medical Biotechnology, Faculty of Medicine and Pharmacy, Mohammed V University in Rabat, Morocco

6 Laboratory of Human Pathologies Biology, Department of Biology, Faculty of Sciences, and Genomic Center of Human Pathologies, Faculty of Medicine and Pharmacy, Mohammed V University in Rabat, Morocco

* Correspondence: boyahyaa-90@ hotmail.fr;

Scopus Author ID 57190813643

Received: 7.01.2021; Revised: 3.02.2021; Accepted: 5.02.2021; Published: 14.02.2021

Abstract: It is difficult to develop a standard extraction method for all types of collagen from different tissues due to the extreme diversity of collagen types. Some procedures are based on the isolation of acid, pepsin, and enzymatic soluble collagen, showing certain advantages and disadvantages. Other methods were also optimized to partially purify collagen and extract it easier than the methods currently used. Indeed, this review describes some advantages and disadvantages of these isolation methods. Moreover, major biomedical applications of collagen were reported. Given the great importance of biocompatible matrices in tissue engineering, the availability of native collagen should be investigated by refining the collagen extraction procedure.

Keywords: collagen; purification; tissue engineering; biomedical applications.

(C) 2021 by the authors. This article is an open-access article distributed under the terms and conditions of the Creative Commons Attribution (CC BY) license (https://creativecommons.org/licenses/by/4.0/).

\section{Introduction}

Collagen is the major component of the extracellular matrix. It is a fibrillar protein composing different conjunctive tissue forms such as bone, cartilage, tendon, and skin [1-4]. Collagen can form insoluble fibrils with high resistance characteristics and can induce or regulate many structural and cellular functions and processes such as differentiation, movement, communication, and apoptosis [5-7].

Type I, II, and III collagens are the most abundant and well investigated for biomedical applications as a plastic material in medicine and cosmetology, but also in the pharmaceutical industry as compounds that prolong the action of drugs $[5,8,9]$, as well as a natural scaffold in tissue engineering and reconstructive medicine (especially type I) [10].

There are almost 20 different types of collagen in humans, each encoded by a specific gene. However, the various types of collagens have slightly different amino acid compositions and perform specific body functions. The main types of collagen are type I (all tissues and 
organs), type II (exclusive to cartilage), type III (skin, blood vessels, and organs), type IV (basement membranes as a system of filtration), and type V (all tissues as a cytoskeleton).

These functions are due to the properties of collagen as a protein. The emphasis on type I collagen is due to its ability to form fibrils with a length of $300 \mathrm{~nm}$ and a fibrillar diameter of up to $1000 \mathrm{~nm}$. This collagen type is trimeric [( $\alpha 1) 2 \beta 2]$ and naturally exists as a triple helix. These helices have "Gly-X-Y" repeats (where X and Y mainly Pro and Hyp). Thus, proline and hydroxyproline, commonly known as imino acids, constitute about $23 \%$ of the total protein sequence, and the Gly-Pro-Hyp structure is the most common form often based [11].

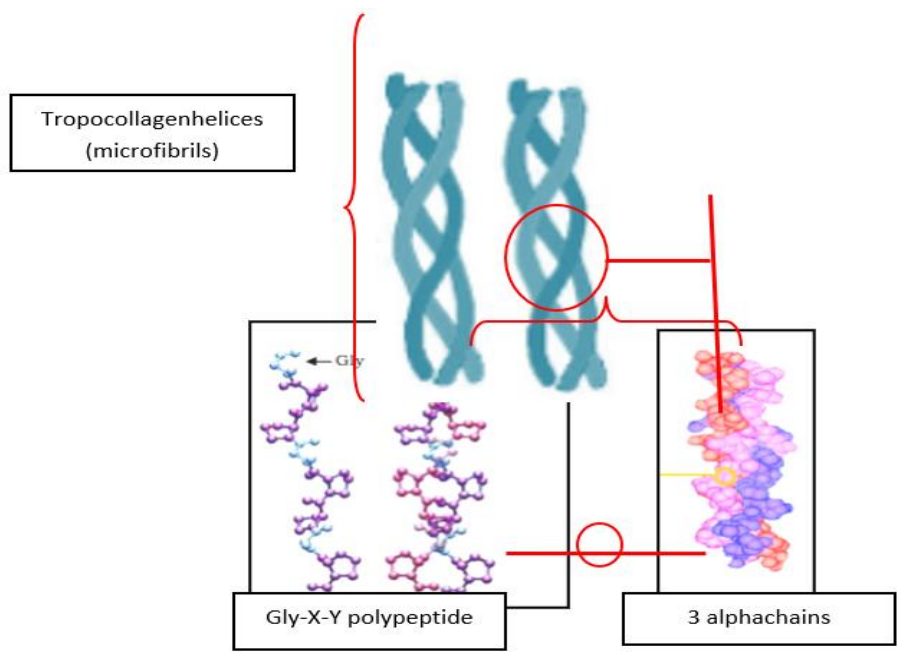

Figure 1. Structure of collagen.

Beyond this extreme diversity of tissues and collagen types, it is important to develop a standard extraction method for all types of collagen and its different sources. The increase over time of the number of covalent intermolecular interactions in collagen structure frequently results in almost complete insolubility in the solvents used for proteins [5, 6, 12]. This work's main objective was to research, study and analyze the known methods of collagen isolation and purification to evaluate their efficiency and optimize them at minimum conditions and normal necessities. The implication for health policy/practice/research/medical education: Physicochemical characterization, as well as all biomedical applications of collagen from different sources, were discussed.

\section{Collagen Isolation and Characterization}

The various types of collagen can be isolated from different sources. In general, the materials are suspended in cold distilled water for 2-3 days, with water changing twice a day. Then the materials are cut into small pieces (about $1 \mathrm{~cm}$ in length).

To isolate the collagen, several methods have been used, such as extraction with neutral salt, acid, and enzymatic solutions [6,13-18]. Indeed, the salt precipitation method was one of the salt extraction procedures based on treating pieces with neutral salt solutions. Then the collagen is isolated by gradually increasing the sodium chloride concentration (adding $\mathrm{NaCl}$ ). The supernatant, containing the salt-soluble collagen fraction, could be dialyzed [14]. At the same time, the acid isolation method is based on extracting collagen from pieces with an organic acid. The supernatant, which contained an acid-soluble fraction of collagen, could be as in the salt method $[5,6]$. The enzymatic isolation method is based on the extraction of collagen with an organic acid in the presence of pepsin. The supernatants of the solutions 
extracted are salted out with $\mathrm{NaCl}$, and the precipitate obtained (content in pure collagen) is dissolved in acetic acid. Then the solution was dialyzed against $\mathrm{Na}_{2} \mathrm{HPO}_{4}$. The general scheme of collagen isolation and purification is shown in figure 1 .

After having tested several collagen isolation procedures, it was noted that the efficiency of the basic salt extraction is low. Also, the solubilization capacity could be obtained by increasing the salt concentration, which will increase the ionic power of the solution obtained. However, in normal tissues, the proportion of neutral salt soluble collagen is usually unimportant, so the final yield is very low.

The alternative method used to ensure the extraction is based on solubilization with dilute organic acid acetic or citric acid used as a solvent the acetic acid in the presence of EDTA, which effectively inhibits tissue degradation. Clearly, in comparison, this method has a greater ability to solubilize collagen than neutral salt extraction but is still limited to young uncrosslinked collagen.

The acid extraction method generally presents a high yield, which was not the case for some studies [19, 20], due to the source (scales) of the first study and the minimum conditions and the simplicity of the materials used in the second. Also, the yield of ASC obtained by [19] was $0.37 \%$ (dry weight basis), which was similar to that of ASC from spotted golden goatfish scales $(0.46 \%)$ [21] but significantly lower than that of ASC from carp scales (0.86\%) [22]. Moreover, Kim and Park [23] mentioned the effectiveness of the pepsin method $(+34 \%$ compared to ASC). The ASC yield was also low for [24] (0.58\% on a dry weight basis), and it was greyish, while the yield of PSC was comparatively higher (16.23\% on a dry weight basis), pinkish, and fiber-like.

The low levels of collagen content may be due to the proteins' denaturation during the process and the difference in ambient temperature [25].

Nagai [26] found less yield of ASC than PSC from diamondback squid (Thysanoteuthis rhombus) skin, which was about $1.3 \%$ on a dry weight basis. On the other hand, the PSC was perfectly solubilized, and its yield was very high, about $35.6 \%$ on a dry weight basis. Additionally, Shanmugam et al. [24] extracted collagen (expressed in dry weight) from the dried skin of Sepiellainermis. However, the collagen content in many animals, on a wet weight basis, reported higher values. Moreover, the pepsin method's yield depends on the concentration of acetic acid used in this manipulation, as demonstrated in the study by Kiew and Mat Don [27] between two different concentrations of $0.7 \mathrm{M}$ and $0.9 \mathrm{M}$, which recorded 26.69 and 20.35 on average, respectively.

On the other hand, the amino acid compositions per 1000 in total showed variation in the composition of collagens. Indeed, the residues of acid-soluble collagen (ASC) and pepsin soluble collagen (PSC) were rich in proline (Pro), glycine (Gly), and hydroxyproline (Hyp), which were due to characteristic (Gly-Pro-Hyp)n, a triple-helical repeat of all collagens. High levels of alanine (Ala), as observed in the collagens of animal species, have also been measured in the fish scale collagens [28].

In addition to Ala, a high level of Hyp was detected, and low levels of His, Hyl and Tyr were generally observed with some cases of Trp absence (case noted in the study of [19]. Except for Cys-s, the other amino acid compositions of these acid-soluble and pepsin-soluble collagen sources were similar to those of ordinary muscle type I collagen [29] and dermal collagen porcine type I [30]. The freshwater fish scales contained relatively high Cys-s, while there were almost no Cys-s detected in other seawater fish collagens [31-35]. The degrees of 
hydroxylation of proline generally varied between extraction methods, which would eventually affect the stability of collagen fibers and denaturation temperatures [30, 33].

The results obtained by analyzing these amino acid determination studies indicated that the experiment of removing non-collagenous proteins was appropriate. Gly is considered the most dominant amino acid in collagen, as known in all members of the collagen family; the results showed the domains with repeats of the proline-rich tripeptides (Gly-XY) involved in the formation of the triple helix, except for the first 14 amino acid residues from the $\mathrm{N}$-terminus and the first 10 amino acid residues from the C-terminus of collagen molecules, where $\mathrm{X}$ is usually Pro and Y is mainly Hyp. On the other hand, the Gly content of ASC-C (347.1 residues/1000 residues) was higher than that (328-341 residues/1000 residues) of ASC from carp scales [36], deep-sea redfish [37], sardine, red sea bream, Japanese sea bass [38], and spotted golden goatfish [39], but lower than those of ASC from rohu (361 residues/1000 residues) and catla (353 residues/1000 residues) scales [40]. Additionally, the amounts of imino acids (Pro and Hyp) are important for collagen's structural integrity. In particular, Hyp is believed to have a major role in stabilizing the triple-stranded collagen helix due to its ability to hydrogen bond through its hydroxyl group. Therefore, the ASC-C helices could be more or less stable depending on the number of residues due to the imino acid content (higher/lower) which the pyrrolidine rings (Pro and Hyp) imposed restrictions on the conformation of the polypeptide chain and helped to enhance the thermal stability of the triple helix [41].

Regarding the denaturation temperature (DT) of ASC from multipurpose sources, it was largely higher than the Td of PSC, mainly due to enzymatic hydrolysis. The DT of the ASC of the used fish scale sources was lower than that of porcine skin collagen but higher than the Td of many cold-water fish collagens measured under the same conditions [42, 39, 43]. Previous studies showed that the stability of collagen is correlated with environmental and body temperatures [44], but current studies have shown that hydroxyproline is important for maintaining the stability of trimmers in collagen [30, 33].

The different Tmax of transitions among collagen from animal species seems to be correlated with the content of imino acids (proline and hydroxyproline). The higher the imino acid content, the more stable the helices [45]. Moreover, the stability of collagen is correlated with room and body temperature [44]. The collagen of cold-water fish has a low imino acid content [46]. Also, the increase in the content of imino acids (proline and hydroxyproline) led to an increase in the DT of collagen [47-49].

In contrast, acetic acid has played an essential role in changing collagen's thermal properties, especially in the skin. In fact, the skin and bone collagens rehydrated in acetic acid exhibited decreases in Tmax and transition enthalpy (DH) compared to those rehydrated in water.

Acetic acid can cleave hydrogen bonds [50], which stabilizes collagen in a triple-helical structure [51]. Thus, the collagen structure has been disrupted, resulting in a decrease in collagens' thermal stability, as shown by the decrease in Tmax and enthalpy. Other studies demonstrated that a DT variation may be due to the type, sex, or age of the resources used [20].

\section{Biomedical Applications}

Collagen is very abundant in nature in various forms and having several properties necessary for different applications in biomedical sciences. Indeed, it is a versatile biomaterial with wide medical applicability. 


\subsection{Tissue regeneration.}

Tissue regeneration or regenerative medicine is the set of techniques using engineering, cell culture, life sciences, and materials sciences to develop biological substitutes that can restore, maintain, or improve tissue functions. It is often based on the use of a scaffold that will serve as a support for the growth of new viable tissue.

\subsubsection{Oral mucosa tissue regeneration.}

Various types of natural and synthetic biomaterials have been used to engineer oral mucosa, including collagen hydrogel from rat-tails and chitosan-fish scale collagen (Table 1). Using primary oral keratinocytes, Terada et al. [52] reported that a chitosan-collagen composite scaffold was constructed by blending commercial chitosan and tilapia scale collagen multilayered, polarized, and stratified epithelial layer with superficial keratinization. In another study, Tabatabaei et al. [53] investigated the viability of collagen hydrogel in the oral mucosa tissue engineering using human primary oral fibroblast and keratinocyte cells that isolated from gingival biopsies. The results showed the seeded keratinocytes' adherence onto the fibroblastpopulated collagen gel and development of a multilayered stratified epithelium on its surface after three days of cultivation, collagen hydrogels encapsulating fibroblasts increased cell viability.

Table 1. Oral mucosa tissue regeneration.

\begin{tabular}{l|l|l|l|l|l} 
Form & Origin & $\begin{array}{l}\text { Extraction } \\
\text { technique }\end{array}$ & $\begin{array}{l}\text { Biological } \\
\text { evaluation }\end{array}$ & References \\
\hline Scaffold & $\begin{array}{l}\text { Tilapia } \\
\text { fish } \\
\text { scales }\end{array}$ & $\begin{array}{l}\text { Freeze-drying } \\
\text { Dehydrothermal } \\
\text { cross-linked }\end{array}$ & $\begin{array}{l}\text { Primary } \\
\text { keratinocytes }\end{array}$ & $\begin{array}{l}\text { Produced sults } \\
\text { polarized, stratified epithelial } \\
\text { layer with superficial } \\
\text { keratinization }\end{array}$ & [52] \\
\hline $\begin{array}{l}\text { Collagen } \\
\text { hydrogel }\end{array}$ & Rat tails & Freeze-drying & $\begin{array}{l}\text { Human primary oral } \\
\text { broblast and } \\
\text { keratinocyte cells }\end{array}$ & $\begin{array}{l}\text { Increased cell viability } \\
\text { Formation of a stratified and } \\
\text { differentiated epithelium on the } \\
\text { surface of cell-laden collagen } \\
\text { hydrogel [53] }\end{array}$ & \\
\hline $\begin{array}{l}\text { Collagen } \\
\text { Peptides }\end{array}$ & $\begin{array}{l}\text { Tilapia } \\
\text { skin }\end{array}$ & & $\begin{array}{l}\text { The tongue mucosa } \\
\text { of C57/BL6 mice }\end{array}$ & $\begin{array}{l}\text { Effectively accelerated the } \\
\text { healing process of oral ulcer }\end{array}$ & [54] \\
\hline $\begin{array}{l}\text { collagen } \\
\text { film }\end{array}$ & & $\begin{array}{l}\text { In vivo on 36 male } \\
\text { chinchilla rabbits }\end{array}$ & $\begin{array}{l}\text { The decrease of clinical signs of } \\
\text { inflammation } \\
\text { Faster and massive growth of } \\
\text { soft tissue }\end{array}$ &
\end{tabular}

3.1.2. Vascular tissue regeneration.

Several approaches have reported that collagen has been used as a biomaterial in various vascular tissue applications because of its excellent biocompatibility (Table 2). Jeong et al. [56] studied the feasibility of jellyfish (Stomolophus nomurim eleagris) collagen as tissue-engineered vascular grafts in pulsatile perfusion bioreactor using vascular smooth muscle cells (SMCs) and endothelial cells (ECs). As a result, it was shown that the co-culturing of SMCs and ECs on collagen/PLGA hybrid scaffolds under a pulsatile perfusion system induced the cellular alignment, the enhancement of vascular EC development, and the retention of differentiated cell phenotype. This study also demonstrated that the jellyfish collagen/PLGA scaffolds up-regulated smooth muscle expressions and endothelial cell activity-related molecules. On the other hand, using mouse lymphatic endothelial cell line, fish scale-derived collagen showed a favorable integration to the surrounding tissues, with good infiltration of 
cells, blood vessels (BVs), and lymphatic vessels (LVs), as well as improved cell attachment and proliferation [57].

\begin{tabular}{l|l|l|l|l|l}
\multicolumn{5}{|c|}{ Table 2. Vascular tissue regeneration. } \\
Form & Origin & Extraction technique & $\begin{array}{l}\text { Biological } \\
\text { evaluation }\end{array}$ & Results & References \\
\hline Scaffold & $\begin{array}{l}\text { Jellyfish } \\
\text { (Stomolophus } \\
\text { nomurim eleagris })\end{array}$ & Electrospinning & $\begin{array}{l}\text { Smoth muscle } \\
\text { cells } \\
\text { Endothelial cells }\end{array}$ & $\begin{array}{l}\text { Enhanced cell proliferation } \\
\text { Induced cell alignment } \\
\text { Up-regulated expressions } \\
\text { smooth muscle and } \\
\text { endothelial cell activity- } \\
\text { related molecules } \\
\text { Enhanced endothelial cell } \\
\text { development }\end{array}$ & \\
\hline Scaffold & Snakehead scales & $\begin{array}{l}\text { Freeze-drying } \\
1,4-\text {-butanediol } \\
\text { diglycidyl ether (BDE) } \\
\text { cross-linked }\end{array}$ & $\begin{array}{l}\text { Mouse } \\
\text { lymphatic } \\
\text { endothelial cell } \\
\text { line }\end{array}$ & $\begin{array}{l}\text { Improved cell attachment, } \\
\text { proliferation and infiltration } \\
\text { Favorable growth of blood } \\
\text { and lymphatic vessels }\end{array}$ & {$[57]$}
\end{tabular}

3.1.3. Skin tissue and wound healing.

Until today, numerous natural and synthetic collagen-based biomaterials have received great attention due to their beneficial biological functions on skin tissue and wound healing [58-80] (Table 3). Indeed, Zhang et al. [59] investigated the wound healing potential of administering marine collagen peptides (MCP) from Chum Salmon (Oncorhyn chusketa) skin using two wound models (incision and excision) in vivo. As a result, it was shown that MCP increased wound closure and improved tissue regeneration at the wound site and improved angiogenesis and helped form thicker and better-organized collagen fiber deposition. The MCP also increased the formation of a capillary, fibroblast, and collagen fiber, the expression of platelet-endothelial cell adhesion molecule-1, basic fibroblast growth factor, and TGF-B1 in rats following cesarean section [62]. Furthermore, the scaffold that was prepared by lowmolecular-weight fish scale collagen peptides (FSCP) and chitooligosaccharides (COS) showed good biocompatibility in vitro and supported the proliferation of human skin fibroblasts [58]. In another work, the fish collagen/alginate (FCA) sponge scaffold improved cell adhesion and proliferation and exhibited the best cellular compatibility in human dermal cells [61]. Vigneswari et al. [63] demonstrated that P(3HB-co-4HB)/FSCP (fish-scale collagen peptides) scaffolds provided better cell attachment and growth of L929 mouse fibroblast cells and better cell proliferation as well as accelerated wound contractions. Using human fibroblasts and keratinocytes, mrigal fish (Cirrhinus cirrhosus) scale scaffolds enhanced cell growth, attachment, and proliferation and increased wound healing rate, re-epithelialization, and dermal reconstitution [64]. Moreover, Zhou et al. [69] demonstrated that fish collagen, obtained from tilapia skin, promoted the adhesion, proliferation, and migration of human keratinocytes. This collagen also induced the secretion of type one collagen and vascular endothelial growth factor by human dermal fibroblasts, further stimulating the proliferation of human vascular endothelial cells and accelerated rat skin wound healing.

Also, Zhang et al. [68] used mouse fibroblasts (NIH-3T3) to evaluate the mechanical properties and the biocompatibility of pepsin-soluble collagen isolated from the skin of Leiocassislongirostris by uniaxial tensile mechanical testing and cell proliferation assay, respectively. In this study, the collagen revealed a denser network structure with thicker fibrils and better uniaxial tensile mechanical properties and could provide a much more suitable environment for cell growth and migration. 
Additionally, Pozzolini et al. [71] studied wound-healing of marine collagen hydrolysates (MCHs)-from the marine sponge C. reniformis using fibroblasts keratinocytes, and the survival of both cells was evaluated after UV radiation. The results showed that $\mathrm{MCH}$ demonstrated promising wound-healing properties, facilitating both cell migration and proliferation at the site of the wound of epidermal and dermal cells. In another study, the various composition chitosan/fish collagen/glycerin 3D porous scaffolds were fabricated via freeze-drying technique and investigated their effect on mechanical strength, biostability, and cytocompatibility in vitro culture of human fibroblasts and keratinocytes. This study showed the good cytocompatibility of scaffolds and excellently facilitated cell proliferation and adhesion [70]. Using the rat wound model, Chen et al. [72] revealed that four types of collagen, including pepsin soluble collagen sponge (PCS), acid-soluble collagen sponge (ACS), bovine collagen electrospun I (BCE I), and bovine collagen electrospun II (BCE II) increased the percentage of wound contraction, reduced the inflammatory infiltration, and accelerated the epithelization and healing. Another work carried out by Wang et al. [73] collagen matrix produced by SCCO 2 technology revealed chemically similar to human skin type I collagen, non-toxic, good biocompatibility, and accelerated wound healing in porcine excision fullthickness skin wound model.

Recently, Ge et al. [79] evaluated the collagen chitosan scaffold's effect alone or enriched with either bone marrow-derived mesenchymal stem cells (BM-MSCs) or their secreted extracellular vesicles (EVs) on the duration and quality of skin wound healing in vivo. The results showed that collagen chitosan scaffolds significantly accelerated the rate of skin healing, enhanced macrophages, and increased collagen deposition. Also, Ge et al. [79] showed that collagen hydrogel fabricated by freeze-drying for Nile tilapia skin (Oreochromis niloticus) accelerated the healing of deep second-degree burns wounds and promoted the formation of new skin appendages. On the other hand, using hamster fibroblasts (V79) native collagen extracted from adult paracentrotuslividus byenzymatical hydrolysis method increased cell proliferation, reduced water evaporation, and protein diffusion, as well as acting as a barrier against bacterial infiltration [78].

\begin{tabular}{|c|c|c|c|c|c|}
\hline Form & Origin & $\begin{array}{l}\text { Extraction } \\
\text { technique }\end{array}$ & Biological evaluation & Results & References \\
\hline Scaffold & $\begin{array}{l}\text { Fish scale collagen peptides } \\
\text { chito-oligosaccharides }\end{array}$ & Electrospinning & Human skin fibroblasts & $\begin{array}{l}\text { Good } \\
\text { biocompatibility in } \\
\text { vitro } \\
\text { Supported } \\
\text { fibroblast } \\
\text { proliferation }\end{array}$ & [58] \\
\hline $\begin{array}{l}\text { Collagen } \\
\text { peptide }\end{array}$ & $\begin{array}{l}\text { Chum salmon } \\
\text { (Oncorhynchusketa) skin }\end{array}$ & $\begin{array}{l}\text { Enzymatical } \\
\text { hydrolysis }\end{array}$ & $\begin{array}{l}\text { Rat wound model (incision } \\
\text { and excision) in vivo }\end{array}$ & $\begin{array}{l}\text { Accelerated the } \\
\text { wound closure } \\
\text { Improved tissue } \\
\text { regeneration at the } \\
\text { wound site } \\
\text { Improved } \\
\text { angiogenesis } \\
\text { Increased } \\
\text { organized collagen } \\
\text { fiber deposition }\end{array}$ & {$[59]$} \\
\hline Scaffold & $\begin{array}{l}\text { Fish scale collagen } \\
\text { Macrotylomauniflorum } \\
\text { extracts }\end{array}$ & $\begin{array}{l}\text { Freeze-drying } \\
\text { Cross-linked } \\
\text { with } \\
\text { glutaraldehyde }\end{array}$ & $\begin{array}{l}\text { NIH-3T3 } \\
\text { HaCaT }\end{array}$ & $\begin{array}{l}\text { Good } \\
\text { biocompatibility } \\
\text { with both cell lines }\end{array}$ & {$[60]$} \\
\hline Scaffold & $\begin{array}{l}\text { Flatfish } \\
\text { (Paralichthysolivaceus) } \\
\text { skin }\end{array}$ & $\begin{array}{l}\text { Freeze-drying } \\
\text { EDC cross- } \\
\text { linked }\end{array}$ & Human dermal cells & $\begin{array}{ll}\text { Induced } & \text { cell } \\
\text { adhesion } & \text { and } \\
\text { proliferation } & \end{array}$ & [61] \\
\hline \multicolumn{5}{|c|}{ https://biointerfaceresearch.com/ } & 13593 \\
\hline
\end{tabular}




\begin{tabular}{|c|c|c|c|c|c|}
\hline Form & Origin & $\begin{array}{l}\text { Extraction } \\
\text { technique }\end{array}$ & Biological evaluation & Results & References \\
\hline & & & & $\begin{array}{lr}\begin{array}{l}\text { Promoted } \\
\text { spread }\end{array} & \text { well- } \\
\text { morphology } & \\
\end{array}$ & \\
\hline $\begin{array}{l}\text { Collagen } \\
\text { peptide }\end{array}$ & $\begin{array}{l}\text { Chum salmon } \\
(\text { Oncorhynchusketa) skin }\end{array}$ & $\begin{array}{l}\text { Enzymatical } \\
\text { hydrolysis }\end{array}$ & $\begin{array}{l}\text { Rat wound model } \\
\text { (following cesarean section) } \\
\text { in vivo }\end{array}$ & $\begin{array}{l}\text { Accelerated the } \\
\text { wound healing } \\
\text { process in rats }\end{array}$ & {$[62]$} \\
\hline Scaffold & Tilapia fish skin & $\begin{array}{l}\text { Cross-linked } \\
\text { with } \\
\text { glutaraldehyde }\end{array}$ & $\begin{array}{l}\text { L929 mouse fibroblast cells } \\
\text { Rat wound model in vivo }\end{array}$ & $\begin{array}{l}\text { Enhanced cell } \\
\text { growth, } \\
\text { attachment, and } \\
\text { proliferation } \\
\text { Accelerated wound } \\
\text { contractions }\end{array}$ & [63] \\
\hline Scaffold & $\begin{array}{l}\text { Mrigal fish } \\
\text { (Cirrhinuscirrhosus) scale }\end{array}$ & $\begin{array}{l}\text { Freeze-drying } \\
\text { Cross-linked } \\
\text { with } \\
\text { glutaraldehyde }\end{array}$ & $\begin{array}{l}\text { Human fibroblasts and } \\
\text { keratinocytes } \\
\text { Rat wound model in vivo }\end{array}$ & $\begin{array}{l}\text { Enhanced cell } \\
\text { growth, } \\
\text { attachment, and } \\
\text { proliferation } \\
\text { Increased wound } \\
\text { healing rate, re- } \\
\text { epithelialization, } \\
\text { and dermal } \\
\text { reconstitution }\end{array}$ & {$[64]$} \\
\hline Scaffold & Fish scale collagen & $\begin{array}{l}\text { Freeze-drying } \\
\text { Cross-linked } \\
\text { with ceftazidime } \\
\end{array}$ & NIH-3T3 fibroblast cell line & $\begin{array}{l}\text { Good } \\
\text { biocompatibility }\end{array}$ & {$[65]$} \\
\hline Scaffold & Weever skin & $\begin{array}{l}\text { Freeze-drying } \\
\text { EDC/NHScross- } \\
\text { linked }\end{array}$ & $\begin{array}{l}\text { Mouse embryonic } \\
\text { fibroblasts cells } \\
\text { Rabbit wound model in vivo }\end{array}$ & $\begin{array}{l}\text { Promoted } \\
\text { biocompatibility } \\
\text { Increased cell } \\
\text { growth and } \\
\text { proliferation } \\
\text { Reduced } \\
\text { inflammation } \\
\text { Enhanced tissue } \\
\text { regeneration and } \\
\text { healing }\end{array}$ & {$[66]$} \\
\hline $\begin{array}{l}\text { Collagen } \\
\text { peptide }\end{array}$ & $\begin{array}{lr}\text { Nile } & \text { tilapia } \\
\text { (Oreochromisniloticus)skin }\end{array}$ & $\begin{array}{l}\text { Enzymatical } \\
\text { hydrolysis }\end{array}$ & $\begin{array}{l}\text { Human keratinocyte } \\
\text { Rabbit scald wound model } \\
\text { in vivo }\end{array}$ & $\begin{array}{l}\text { Increased cell } \\
\text { proliferation } \\
\text { Promoted wound } \\
\text { healing }\end{array}$ & [67] \\
\hline Scaffold & Leiocassislongirostrisskin & $\begin{array}{ll}\text { EDC } & \text { cross- } \\
\text { linked } & \end{array}$ & $\begin{array}{l}\text { Mouse fibroblasts }(\mathrm{NIH}- \\
\text { 3T3) }\end{array}$ & $\begin{array}{ll}\begin{array}{l}\text { Facilitated } \\
\text { proliferation }\end{array} & \text { cell } \\
\text { migration } & \text { and } \\
\end{array}$ & [68] \\
\hline Scaffold & Tilapia skin & Electrospinning & $\begin{array}{l}\text { Human keratinocytes } \\
\text { (HaCaT) } \\
\text { Human dermal fibroblasts } \\
\text { (HDFs) } \\
\text { Rat skin defect model in } \\
\text { vivo }\end{array}$ & $\begin{array}{l}\text { Promoted the } \\
\text { adhesion, } \\
\text { proliferation, and } \\
\text { migration } \\
\text { HaCaT } \\
\text { Induced of } \\
\text { secretion of type I } \\
\text { collagen and } \\
\text { vascular } \\
\text { endothelial growth } \\
\text { factor by HDFs } \\
\text { Accelerated rat } \\
\text { skin wound healing }\end{array}$ & [69] \\
\hline Scaffold & Tilapia fish scale & Freeze-drying & $\begin{array}{l}\text { Human keratinocytes and } \\
\text { fibroblasts }\end{array}$ & $\begin{array}{l}\text { Good } \\
\text { cytocompatibility } \\
\text { Facilitated cell } \\
\text { proliferation and } \\
\text { adhesion }\end{array}$ & [70] \\
\hline $\begin{array}{l}\text { Collagen } \\
\text { peptide }\end{array}$ & Chondrosiareniformis & $\begin{array}{l}\text { Enzymatical } \\
\text { hydrolysis }\end{array}$ & $\begin{array}{l}\text { Mouse macrophage cell line } \\
\text { Mouse fibroblast L929 cell } \\
\text { line } \\
\text { HaCaT }\end{array}$ & $\begin{array}{l}\text { Increased cell } \\
\text { proliferation } \\
\text { Induced a photo- } \\
\text { protective effect }\end{array}$ & [71] \\
\hline Scaffold & Tilapia skin & Freeze-drying & Rat wound model in vivo & $\begin{array}{l}\text { Increased wound } \\
\text { contraction }\end{array}$ & [72] \\
\hline
\end{tabular}




\begin{tabular}{|c|c|c|c|c|c|}
\hline Form & Origin & $\begin{array}{l}\text { Extraction } \\
\text { technique }\end{array}$ & Biological evaluation & Results & References \\
\hline & & & & $\begin{array}{l}\text { Reduced } \\
\text { inflammatory } \\
\text { reaction } \\
\text { Enhanced collagen } \\
\text { synthesis and } \\
\text { dermal } \\
\text { reconstitution } \\
\text { Accelerated the } \\
\text { epithelization and } \\
\text { wound healing }\end{array}$ & \\
\hline $\begin{array}{l}\text { Collagen } \\
\text { matrix }\end{array}$ & Porcine skin & Freeze-drying & $\begin{array}{l}\text { Fibroblastsandkeratinocytes } \\
\text { Pig wound model in vivo }\end{array}$ & $\begin{array}{l}\text { No toxic effect } \\
\text { Excellent } \\
\text { biocompatibility } \\
\text { (in vivo et in vitro) } \\
\text { Decreased } \\
\text { inflammation, } \\
\text { completed } \\
\text { epithelization, and } \\
\text { enhanced wound } \\
\text { healing (in vitro) }\end{array}$ & [73] \\
\hline $\begin{array}{l}\text { Collagen } \\
\text { hydrogel }\end{array}$ & Porcine skin & Freeze-drying & $\begin{array}{ll}\text { Human } & \text { epidermal } \\
\text { keratinocytes } & \end{array}$ & $\begin{array}{l}\text { Induced fast and } \\
\text { superior skin } \\
\text { regeneration in a } \\
\text { non-healing wound } \\
\text { model in diabetic } \\
\text { mice }\end{array}$ & [74] \\
\hline $\begin{array}{l}\text { Collagen- } \\
\text { chitosan } \\
\text { membranes }\end{array}$ & Porcine skin & $\begin{array}{l}\text { Cross-linked } \\
\text { with alginate } \\
\text { dialdehyde }\end{array}$ & $\begin{array}{l}\text { L929 fibroblasts cells } \\
\text { Rat skin resection wound }\end{array}$ & $\begin{array}{l}\text { No cytotoxicity } \\
\text { toward L929 } \\
\text { fibroblasts } \\
\text { Good } \\
\text { biocompatibility } \\
\text { Promoted wound } \\
\text { healing in vivo }\end{array}$ & [75] \\
\hline Scaffold & Skin of newborn lambs & Freeze-drying & $\begin{array}{l}\text { Rat wound model in vivo } \\
\text { Bone marrow-derived } \\
\text { mesenchymal stem cells }\end{array}$ & $\begin{array}{l}\text { Improved wound } \\
\text { healing }\end{array}$ & [76] \\
\hline Scaffold & Bovine tendons & Freeze-drying & $\begin{array}{l}\text { Bone mesenchymal stem } \\
\text { cells } \\
\text { Rat wound model in vivo }\end{array}$ & $\begin{array}{l}\text { Increased cell } \\
\text { adhesion, viability, } \\
\text { and differentiation } \\
\text { Improved wound } \\
\text { healing (in vivo) }\end{array}$ & [77] \\
\hline $\begin{array}{l}\text { Native } \\
\text { collagen }\end{array}$ & Adult Paracentrotuslividus & $\begin{array}{l}\text { Enzymatical } \\
\text { hydrolysis }\end{array}$ & Hamster fibroblasts (V79) & $\begin{array}{l}\text { Increased cell } \\
\text { proliferation } \\
\text { Reduced water } \\
\text { evaporation and } \\
\text { protein diffusion } \\
\text { Acted as a barrier } \\
\text { against bacterial } \\
\text { infiltration }\end{array}$ & [78] \\
\hline $\begin{array}{l}\text { Collagen } \\
\text { hydrogel }\end{array}$ & $\begin{array}{l}\text { Nile Tilapia Skin } \\
\text { (Oreochromisniloticus) }\end{array}$ & Freeze-drying & $\begin{array}{l}\text { NIH-3T3 fibroblast cell line } \\
\text { Rats' skin-deep second- } \\
\text { degree burns }\end{array}$ & $\begin{array}{l}\text { No significant } \\
\text { toxicity to } \\
\text { fibroblasts } \\
\text { Accelerated the } \\
\text { healing of deep } \\
\text { second-degree } \\
\text { burn wounds } \\
\text { Promoted the } \\
\text { formation of new } \\
\text { skin appendages }\end{array}$ & [79] \\
\hline
\end{tabular}

3.1.4. Bone tissue regeneration.

Bone tissue is constantly changing; this process gives a bone the self-healing properties. However, in some cases, this natural self-repair process is insufficient because of mechanical or biological problems. Therefore, bone reconstruction must be assisted; this is the stake in the bioengineering of bone. In fact, biomaterial-based bone grafts have an important role in the 
field of bone tissue engineering. In this context, several studies show that collagen, particularly the collagens of marine origin, has interesting osteoconductive and biomechanical properties and is applied increasingly in tissue engineering [81-99] (Table 4).

Pallela et al. [96] evaluated the scaffold (Chi-HAp-MSCol) derived from Thunnus obesus bone and marine sponge (Irciniafusca) collagen (MSCol) on MG-63 cell line in vivo. This scaffold was prepared using the freeze-drying and lyophilization method. According to this study, these biomimetic scaffolds have potential in the field of bone tissue engineering [96]. Also, the collagen extracted from the freshwater fish origin, using a technique of extraction called Freeze-drying Cross-linking using 1-ethyl-3- (3-dimethyl-aminopropyl) carbodiimide (EDC), was evaluated for its biocompatibility and immunogenicity in vitro on fibroblasts (3T3) cells and human osteosarcoma cells (MG63), and in vivo using the mouse model. The results revealed a significant proliferation rate of cells on the scaffolds, and in 5 days, the cells were fully confluent [96]. The addition of Aquamin to the collagen-GAG biomaterial has improved osteoblasts' mineralization and enhanced osteogenesis to facilitate bone repair in vivo [90]. Moreover, Xu et al. [91] showed that the marine collagen peptides (MCP) derived from chum salmon (Oncorhyn chusketa) skin on the development of femurs in growing rats; the result showed that the MCP increases the size, mineral density, dry weight, ash weight, most mineral content and both stiffness and toughness of the femurs in growing male rats [91]. In another study, Mredha et al. [88] developed a novel class of collagen fibrilbased tough hydrogels based on the double network (DN) collagen (SBC), extracted from Bester sturgeon fish. The implantation of the gels in the rabbit knee's osteochondral defect showed that these DN hydrogels exhibit excellent biomechanical performance in vivo and have a strong bonding ability with bone [88].

The evaluation of physicochemical and morphological characteristics, as well as biological performance in vitro of the association of HA (hydroxyapatite) and SPG (called spongin) composites, showed that this combination improves the biological properties, in particular those mimicking bone composition (with 70\% HA and 30\% SPG) [86]. In another study, [74] found that the biphasic scaffold develops from marine collagens are a suitable setup for in vitro chondrogenic and osteogenic differentiation of human mesenchymal stromal cells (hMSC). Also, Nabavi et al. [83] prepared collagen-based hydrogel scaffolds containing tacrolimus and surrounded by a PCL/gelatin membrane; the results provide evidence of the developed efficacy hydrogel for the treatment of bone defects. In vitro and in vivo biological assessments of collagen scaffolds, fabricated via the SSM model, improved osteogenesis of rBMSCs and modulated the macrophage response, thus positively affecting bone regeneration [82].

Tsai et al. [81] used HANF fragments to evaluate the effects of COL-HANF scaffolds on MG63 osteoblast-like cell behaviors, in vitro and in vivo properties showed that COLHANF scaffold has potential as a bone graft for bone tissue engineering; in addition, the scaffolds have promoted the differentiation of MG63 osteoblast-like cells. Furthermore, Matsumoto et al. [98] studied Tilapia scale collagen fibril's effect on the differentiation of human mesenchymal stem cells (hMSCs). According to this study, the hMSCs adhered easily to tilapia scale collagen, which accelerated the early stage of osteoblastic differentiation in hMSCs in vitro cell culture. In another study, Hu et al. [67] investigated the therapeutic effects of collagenous peptides extracted from scales of two kinds of fish on the Human MG-63 osteosarcoma cell line. The results indicated that collagenous peptides promoted the 
proliferation of osteoblasts; therefore, could be used to prevent osteoporosis from assisting bone remodeling [67].

Table 4. Bone tissue regeneration.

\begin{tabular}{|c|c|c|c|c|c|}
\hline Form & Origin & Extraction technique & $\begin{array}{l}\text { Biological } \\
\text { evaluation }\end{array}$ & Results & References \\
\hline $\begin{array}{l}\text { Collagen } \\
\text { peptide }\end{array}$ & $\begin{array}{l}\text { Growing rat femora } \\
\text { model (in vivo) }\end{array}$ & Enzymatical hydrolysis & $\begin{array}{l}\text { Chum salmon } \\
(\text { Oncorhyn } \\
\text { chusketa) skin }\end{array}$ & $\begin{array}{l}\text { Enhanced stiffness and } \\
\text { toughness of femurs } \\
\text { Increased size, weight, } \\
\text { and mineral density } \\
\text { and content of femurs }\end{array}$ & [91] \\
\hline Insoluble & Purchased & $\begin{array}{l}\text { EDC and NHScross- } \\
\text { linked }\end{array}$ & $\begin{array}{l}\text { Human bone } \\
\text { marrow cells }\end{array}$ & $\begin{array}{l}\text { Incorporated on the } \\
\text { surface of the porous } \\
\text { hydroxyapatite } \\
\text { scaffolds }\end{array}$ & [97] \\
\hline Scaffold & $\begin{array}{l}\text { Thunnusobesus bone } \\
\text { and marine sponge } \\
(\text { Irciniafusca) collagen }\end{array}$ & $\begin{array}{l}\text { Freeze-drying and } \\
\text { lyophilization method }\end{array}$ & $\begin{array}{l}\text { Human MG-63 } \\
\text { osteosarcoma cell } \\
\text { line }\end{array}$ & $\begin{array}{l}\text { Promoted cell } \\
\text { proliferation }\end{array}$ & [96] \\
\hline Scaffold & $\begin{array}{l}\text { Fish scales of Rohu and } \\
\text { Catla }\end{array}$ & $\begin{array}{l}\text { Freeze-drying } \\
\text { Cross-linking using } 1 \text { - } \\
\text { ethyl-3-(3-dimethyl- } \\
\text { aminopropyl)- } \\
\text { carbodiimide (EDC) }\end{array}$ & $\begin{array}{l}\text { Fibroblasts (3T3) } \\
\text { cells } \\
\text { Human } \\
\text { osteosarcoma } \\
\text { cells (MG63) } \\
\text { Mouse model (in } \\
\text { vivo) }\end{array}$ & $\begin{array}{lr}\text { Elicited } & \text { minimal } \\
\text { inflammatory response } \\
\text { Promoted } & \text { cell } \\
\text { proliferation } & \end{array}$ & [95] \\
\hline $\begin{array}{l}\text { Collagen } \\
\text { peptide }\end{array}$ & $\begin{array}{l}\text { Bone and skin from } \\
\text { cods }\end{array}$ & Enzymatical hydrolysis & $\begin{array}{l}\text { Human } \\
\text { osteoblasts }\end{array}$ & $\begin{array}{l}\text { Promoted cell } \\
\text { proliferation } \\
\text { Up-regulated the } \\
\text { expression of the } \\
\text { osteogenic markers } \\
\text { Accelerated the matrix } \\
\text { mineralization }\end{array}$ & [94] \\
\hline $\begin{array}{l}\text { Collagen } \\
\text { peptide }\end{array}$ & $\begin{array}{ll}\text { Gadiformes } & \text { and } \\
\text { Pleuronectidae } & \end{array}$ & Enzymatical hydrolysis & $\begin{array}{l}\text { Mouse calvaria- } \\
\text { derived MC3T3- } \\
\text { E1 cells }\end{array}$ & $\begin{array}{l}\text { Up-regulated the } \\
\text { expression of collagen } \\
\text { modifying enzymes } \\
\text { Increased collagen } \\
\text { deposition } \\
\text { Accelerated the matrix } \\
\text { mineralization }\end{array}$ & [93] \\
\hline $\begin{array}{l}\text { Collagen } \\
\text { peptide }\end{array}$ & Scale of tilapia & Enzymatical hydrolysis & $\begin{array}{l}\text { Rat bone marrow- } \\
\text { derived } \\
\text { mesenchymal } \\
\text { stem cells }\end{array}$ & $\begin{array}{l}\text { Promoted cell viability } \\
\text { Up-regulated the } \\
\text { expression of the } \\
\text { osteogenic markers } \\
\text { Up-regulated the } \\
\text { expression of the } \\
\text { endothelial marker }\end{array}$ & {$[92]$} \\
\hline $\begin{array}{l}\text { Native } \\
\text { collagen }\end{array}$ & Tilapia scale collagen & Freeze-drying & $\begin{array}{l}\text { Human } \\
\text { mesenchymal } \\
\text { stem cells } \\
\text { (hMSCs) }\end{array}$ & $\begin{array}{l}\text { Accelerated the early } \\
\text { stage of osteoblastic } \\
\text { differentiation } \\
\text { Up-regulated the } \\
\text { osteoblastic markers }\end{array}$ & [98] \\
\hline Scaffold & $\begin{array}{l}\text { Glycosaminoglycan } \\
\text { Aquamin }\end{array}$ & $\begin{array}{l}\text { Freeze-drying } \\
\text { Dehydrothermal (DHT) } \\
\text { cross-linking treatment }\end{array}$ & $\begin{array}{ll}\text { Mouse } & \text { pre- } \\
\text { osteoblast } & \\
\text { MC3T3-E1 } & \text { cell } \\
\text { line } & \\
\end{array}$ & $\begin{array}{l}\text { Improved } \\
\text { mineralization }\end{array}$ & [90] \\
\hline $\begin{array}{l}\text { Collagen } \\
\text { peptide }\end{array}$ & Sparidae and Chanos & Enzymatical hydrolysis & $\begin{array}{l}\text { Human MG-63 } \\
\text { osteosarcoma cell } \\
\text { line }\end{array}$ & $\begin{array}{l}\text { Promoted the } \\
\text { proliferation of } \\
\text { osteoblasts } \\
\text { Inhibited the } \\
\text { proliferation of mature } \\
\text { osteoclasts }\end{array}$ & [67] \\
\hline Scaffold & $\begin{array}{l}\text { Blue shark } \\
(\text { Prionaceglauca }) \\
\text { cartilage }\end{array}$ & $\begin{array}{l}\text { Freeze-drying } \\
\text { Glutaraldehyde } \\
\text { linked }\end{array}$ & $\begin{array}{l}\text { Human acute T- } \\
\text { lymphocyte } \\
\text { leukemia cell lines } \\
\text { (6T-CEM) } \\
\text { Human fetal } \\
\text { osteoblasts }\end{array}$ & $\begin{array}{l}\text { Increased cell viability } \\
\text { Enhanced the alkaline } \\
\text { phosphatase activity }\end{array}$ & [100] \\
\hline
\end{tabular}




\begin{tabular}{|c|c|c|c|c|c|}
\hline Scaffold & Rat-tail tendon & Neutralization & $\begin{array}{l}\text { Mesenchymal } \\
\text { dental pulp stem } \\
\text { cell simplanted in } \\
\text { a rat critical-sized } \\
\text { calvarial defect } \\
\text { model }\end{array}$ & $\begin{array}{l}\text { Restored the } \\
\text { osteoblastic forming } \\
\text { and osteoclastic } \\
\text { resorbing processes }\end{array}$ & [89] \\
\hline Scaffold & $\begin{array}{l}\text { Swim bladder of Bester } \\
\text { sturgeon fish }\end{array}$ & $\begin{array}{ll}\text { Glutaraldehyde } & \text { and } \\
\text { genipin cross-linked }\end{array}$ & $\begin{array}{l}\text { Rabbit } \quad \text { bone } \\
\text { defect model in } \\
\text { vivo }\end{array}$ & $\begin{array}{l}\text { Good biomechanical } \\
\text { performance } \\
\text { Strong bonding ability } \\
\text { with bone }\end{array}$ & [88] \\
\hline Scaffold & $\begin{array}{l}\text { Sharkskin } \\
\text { (Prionaceglauca) } \\
\text { collagen } \\
\text { Shark teeth bioapatite }\end{array}$ & $\begin{array}{l}\text { Freeze-drying } \\
\text { Cross-linking using } \\
\text { EDC/NHS (N- } \\
\text { Hydroxysuccinimide) and } \\
\text { hexamethylene } \\
\text { diisocyanate (HMDI) }\end{array}$ & $\begin{array}{l}\text { Human } \\
\text { osteoblast-like } \\
\text { cell line (Saos-2) }\end{array}$ & Increased cell viability & [87] \\
\hline Scaffold & $\begin{array}{ll}\text { Marine } & \text { sponge } \\
\text { Aplysinafulva } & \end{array}$ & Vacuum drying & $\begin{array}{l}\text { Mouse fibroblasts } \\
\text { (L929) } \\
\text { Mouse pre- } \\
\text { osteoblastic cells } \\
(\text { MC3T3-E1) } \\
\end{array}$ & Promoted cell viability & [86] \\
\hline Scaffold & $\begin{array}{l}\text { Biomimetically } \\
\text { mineralized salmon } \\
\text { collagen and fibrillated } \\
\text { jellyfish collagen }\end{array}$ & $\begin{array}{l}\text { Freeze-drying } \\
\text { EDC cross-linked }\end{array}$ & $\begin{array}{l}\text { Bone marrow- } \\
\text { derived human } \\
\text { mesenchymal } \\
\text { stromal cells }\end{array}$ & $\begin{array}{l}\text { Induced chondrogenic } \\
\text { and osteogenic } \\
\text { differentiation }\end{array}$ & [85] \\
\hline Scaffold & Fish scale and skin & Electrospinning & $\begin{array}{l}\text { Bone } \\
\text { mesenchymal } \\
\text { stem cells } \\
\text { Human gingiva } \\
\text { fibroblasts cells }\end{array}$ & $\begin{array}{l}\text { Improved } \\
\text { cytocompatibility } \\
\text { Enhanced the } \\
\text { mechanical strength } \\
\text { and accelerated the } \\
\text { degradation rate }\end{array}$ & [84] \\
\hline Scaffold & Rat-tail tendon & EDC cross-linked & $\begin{array}{l}\text { Human } \\
\text { osteosarcoma cell } \\
\text { line } \\
\text { Rat calvarias } \\
\text { defect modelin } \\
\text { vivo } \\
\end{array}$ & $\begin{array}{l}\text { Promoted in vitro cell } \\
\text { proliferation } \\
\text { Induced the bone } \\
\text { healing (in vivo) }\end{array}$ & [83] \\
\hline Scaffold & $\begin{array}{l}\text { Rat (Sprague-Dawley) } \\
\text { tail tendon fascicles }\end{array}$ & $\begin{array}{l}\text { Lyophilization } \\
\text { EDC and NHScross- } \\
\text { linked }\end{array}$ & $\begin{array}{l}\text { Rat bone marrow } \\
\text { mesenchymal } \\
\text { stromal cells }\end{array}$ & $\begin{array}{l}\text { Promoted in vitro cell } \\
\text { proliferation and } \\
\text { osteogenic } \\
\text { differentiation } \\
\text { Improved osteogenesis } \\
\text { by altering the } \\
\text { macrophage response }\end{array}$ & [82] \\
\hline Scaffold & Calfskin & $\begin{array}{l}\text { Freeze-drying } \\
\text { EDC cross-linked }\end{array}$ & $\begin{array}{l}\text { MG63 osteoblast- } \\
\text { like cell } \\
\text { Rabbit condylar } \\
\text { defect model in } \\
\text { vivo }\end{array}$ & $\begin{array}{l}\text { Promotedcell } \\
\text { proliferation } \\
\text { Promoted } \\
\text { regeneration }\end{array}$ & [81] \\
\hline Scaffold & $\begin{array}{l}\text { Human-like collagen } \\
\text { (HLC) }\end{array}$ & & $\begin{array}{l}\text { MC3T3-E1 } \\
\text { osteoblast cells }\end{array}$ & $\begin{array}{l}\text { Excellent mechanical } \\
\text { and superior biological } \\
\text { properties for bone } \\
\text { tissue regeneration }\end{array}$ & [101] \\
\hline
\end{tabular}

\subsubsection{Cartilage tissue regeneration.}

Deformities or damage to the cartilaginous facial structures (nose or auricle) can occur due to trauma, tumor resection, or congenital disabilities. Reconstruction of these defects requires intervention using autologous grafts such as a rib or ear cartilage or synthetic materials such as Gore-Tex or silicone. Nevertheless, there is a need for new cartilage replacement strategies, such as tissue engineering, which is based on the use of autologous chondrocytes and resorbable matrices (Table 5). To this end, a study conducted by Bermueller et al. [102] demonstrated that marine collagen matrices offer excellent properties for cartilage tissue engineering, using marine collagen scaffolds, thus preventing septal perforation in an autologous and orthotopic rat model. In this sense, and during this study, it was possible on the 
one hand to study the relevance of marine collagen as a replacement matrix for cartilage in the context of three-dimensional cultures in vitro by analyzing cell migration, cytotoxicity, and extracellular matrix formation using human and rat nasal septal chondrocytes.

On the other hand, the researchers proceeded to develop an orthotopic animal model suitable for the repair of the nasal septum while at the same time evaluating the biocompatibility of marine collagen. For this purpose, histological and immunohistochemical evaluation of seeded and unseeded scaffolds transplanted into nasal septum defects in an orthotopic rat model (for 1, 4, and 12 weeks) showed that the scaffolds did not induce any cytotoxic reactions in vitro. The chondrocytes were able to adhere to marine collagen and produce cartilage matrix proteins, such as type II collagen. Likewise, treatment of septal cartilage defects in vivo with seeded and unseeded scaffolds resulted in a significant reduction in the number of nasal septal perforations compared to no replacement. This novel experimental surgical procedure provides a suitable means to evaluate new scaffolding materials for their applicability in repairing nasal cartilage. In another research work carried out by (Ohnishi et al. [103] on 12 rabbits, in which osteoarthritis was induced, the researchers studied the correlations of the severity of osteoarthritis (OA) and serum biomarkers extracted from the collagen of Gadiformes fish species, including the epitope of keratan sulfate, hyaluronic acid, and chondroitin sulfate 846. Likewise, during this study, the effect of glucosamine and collagen peptide extracted from fish on osteoarthritis was also investigated. Osteoarthritis was induced in 12 rabbits (12 weeks old) by anterior cruciate ligament transection. After the surgery, the rabbits were orally administered fish collagen peptide (group F), glucosamine (group G) or fish collagen peptide, and glucosamine (group FG) for 4 weeks. The control group received water ad libitum (group C). Also, to measure serum markers, blood samples were taken before surgery (pre-transaction of the anterior cruciate ligament) and before euthanasia (post-transection of the anterior cruciate ligament).

During this study, a macroscopic and histological assessment of the severity of osteoarthritis was performed. The results showed that the condylar surfaces were slightly eroded in group C. Additionally, the histological results were significantly different from those of the FG group and the other groups. There were no significant differences between each group during anterior cruciate ligament transection in terms of serum keratan sulfate, hyaluronic acid, and chondroitin sulfate 846.

Histological evaluation and serum biomarker measurements performed after anterior cruciate ligament transection showed a significant correlation between hyaluronic acid concentration and the severity of osteoarthritis. Changes in chondroitin sulfate 846 concentration at the pre-anterior cruciate ligament and post-anterior cruciate ligament transection levels were significantly correlated with osteoarthritis severity.

Administration of glucosamine and fish collagen peptide had chondroprotective effects in the anterior cruciate ligament transection model. Serum biomarker concentrations were significantly correlated with cartilage damage. Measurement of serum biomarkers would be useful for monitoring articular cartilage damage in clinical settings.

Tilapia Fish collagen may provide a suitable collagen source for chondrogenesis of human mesenchymal stem cells (hMSCs) in vitro; a novel alternative to conventional mammalian collagens such as bovine and porcine collagen. In another study conducted by Hsu et al. [104], researchers investigated the chondrogenic differentiation of hMSCs grown on tilapia-scale collagen fibrils compared to porcine collagen uncoated dishes. This research study showed that fish collagen could overcome zoonosis risk, like that of bovine spongiform 
encephalopathy. In particular, tilapia collagen, whose denaturation temperature is close to $37^{\circ} \mathrm{C}$, was ideal for cell and tissue culture. In this study, the scanning electron microscope was used to observe collagen fibrils. Safranin O staining, expression of glycosaminoglycans (GAGs), showed that hMSCs cultured on collagen at the tilapia scale exhibited stronger safranin $\mathrm{O}$ staining and higher expression of GAGs on day 6.

Real-time PCR was also used to assess the chondrogenesis of hMSCs on each type of collagen fibrils showing that hMSCs has grown on tilapia collagen exhibited earlier expression of SOX9 on day 4 with higher expression of AGGRECAN and COLLAGEN II on day 6 compared to porcine collagen and uncoated dishes. Furthermore, low bone gammacarboxyglutamate mRNA levels, a specific osteogenesis marker, showed that tilapia collagen fibrils specifically enhance chondrogenic differentiation of hMSCs in chondrogenic media, as well as porcine collagen. Therefore, tilapia scale collagen can provide a suitable collagen source for chondrogenesis of hMSCs cultured in vitro. In the same context of using collagen extracted from fish, marine hybrid constructions of porous scaffolds from fibrillated jellyfish collagen and alginate hydrogel mimic the two main components' cartilage tissue. This constitutes a promising approach for the chondrogenic differentiation of hMSCs. Indeed, a study by Pustlauk et al. [105] showed the potential of hybrid scaffolds based on marine biomaterials-hydrogel alginate in repairing articular cartilage, and this by examining scaffolds either infiltrated with an alginate cell suspension or seeded with hMSCs and incorporated in the alginate after cell adhesion. The researchers also compared the hybrid constructs with $2 \mathrm{x}$ 105 and $4.5 \times 105 \mathrm{hMSCs} / \mathrm{scaffold}$ and hMSCs encapsulated in pure alginate discs, both chondrogenically stimulated for 21 days. They revealed a typical round chondrocyte-like morphology in pure alginate gels and alginate-cell-suspension scaffolds, while the cells of the scaffolds embedded in the alginate after seeding had an elongated shape and were tightly attached to the collagen pores. However, the $\mathrm{Col} 2 / \mathrm{Col} 1$ ratio was higher for pure alginate discs and alginate cell suspension scaffolds than for scaffolds embedded in alginate after seeding. Compared to the porous hydrogel-free jellyfish collagen scaffolds, hMSCs embedded in hybrid scaffolds showed higher gene expression of chondrogenic markers. Additionally, the secretion of sulfated glycosaminoglycans was comparable for the alginate cell suspension scaffolds and the scaffolds incorporated into the alginate after seeding. Finally, the results of this study showed that hybrid collagen and alginate constructs from jellyfish support chondrogenic differentiation of hMSCs and provide more stable constructs compared to pure hydrogels. Accordingly, another study performed by Diogo et al. [106], whose findings were consistent with the previous study, highlighted the relevance of using blue shark collagen biopolymer as a building block to produce highly efficient temporary matrices in cartilage applications. This in vitro study revealed that human adipose-derived stem cells (hASCs) adhere abundantly to constructs, thus promoting early chondrogenic differentiation of these cells. This work addressed the potential of 3D collagen-based structures of blue shark (Prionaceglauca) skin to promote the differentiation of hASCs into a chondrogenic lineage with and without exogenous stimulation. The cryogelation method was applied using a mixture with hyaluronic acid to enhance the constructs' microporous interconnectivity [107]. The interconnected microporous structures have been shown to promote cell adhesion and cell proliferation and extracellular matrix (ECM) formation and infiltration in scaffolds, showing great potential for regeneration of cartilage tissue, especially when considering the use of cellfree strategies. The results obtained confirm $P$. glauca cutaneous collagen's biomedical applicability, representing a strategy for enhancing marine by-products. 
The potential of blue shark ( $P$. glauca) skin collagen to induce chondrogenic differentiation of hASCs was investigated, with and without exogenous stimulation. For this purpose, a cryogelation method has been applied to produce highly interconnected porous three-dimensional constructs based on collagen and hyaluronic acid. These results are supported by the expression of markers encoding chondrogenesis-related mRNA (Coll II and Sox-9), which are strongly up-regulated at an early stage for both conditions, with or without exogenous stimulation. This assumes that $P$. glauca collagen itself can support chondrogenic differentiation at early times, but exogenous stimulation is required to ensure the phenotype's maintenance. Likewise, Raabe et al. [108] evaluated the potential of hydrolyzed fish collagen in the differentiation and chondrogenesis of stromal cells derived from equine adipose tissue, and therefore, the application of stromal cells derived from adipose tissue in equine veterinary tissue engineering, especially for repairing cartilage. To do this, this work focused on the study of the effect of transforming growth factor beta1 (TGF-B1) compared to hydrolyzed fish collagen in terms of the chondrogenic differentiation potential of stromal cells derived from adipose tissue, knowing that these cells are multipotent cells which, in the presence of appropriate stimuli, can differentiate into various lineages such as osteogenic, adipogenic, and chondrogenic cells. In this study, stromal cells derived from adipose tissue were isolated from horses' subcutaneous fat by liposuction. Chondrogenesis was studied using a pellet culture system. The differentiation medium was either supplemented with the growth factor of TGFB1 $(5 \mathrm{mg} / \mathrm{mL})$ or fish collagen $(0.5 \mathrm{mg} / \mathrm{mL})$ during 3 weeks of differentiation in vitro. Moreover, examining the degree of chondrogenic differentiation and the formation of the cartilage extracellular matrix was carried out using the RT-PCR technique and histological staining to synthesize proteoglycans and type II collagen.

The differentiation of adipose tissue-derived stromal cells induced by TGF-B1 showed a high expression of GAG. Histological analysis of cultures stimulated with hydrolyzed fish collagen demonstrated even higher GAG expression than cultures stimulated under standard conditions with TGF-B1.

The expression of cartilage-specific type II collagen and Sox9 was approximately the same in the two stimulated cultures. In this study, chondrogenesis was induced as efficiently by hydrolyzed fish collagen as by TGF-B1. The results demonstrated that hydrolyzed fish collagen alone can induce and maintain chondrogenesis derived from stromal cells derived from adipose tissue.

Many approaches in this field have shown partially satisfactory results. Cartilage tissue engineering, combining innovative scaffolds and stem cells from different sources, appears to be a promising strategy for cartilage regeneration. To this end, another recent study conducted in rats by Szychlinska et al. [109] aimed to assess the ability of a type I collagen scaffold to promote cartilage repair after orthotopic implantation in vivo.

Articular cartilage lesions were created at the patellofemoral groove in rat knees with type I collagen scaffolds implantation. At 4, 8, and 16 weeks after transplantation, degrees of cartilage repair was assessed by morphological, histochemical, and gene expression analyzes. This study's conclusions are in line with previous studies [102-103], which suggested that the collagen-based scaffold, especially type I, is highly biocompatible and able to recruit host cells from surrounding joint tissue to promote cartilage repair of joint defects. In a recent study, led by Zhang et al. [110], authors developed an injectable hydrogel system composed of collagen I-tyramine and hyaluronic acid-tyramine and built bone marrow mesenchymal stem cells and a hydrogel-charged system for cartilage regeneration. The first results showed that this 
injectable hydrogel could be used ideally in the regeneration of cartilage tissues. Then, this hydrogel system's physicochemical properties were well characterized and optimized, in particular the gel time, the rigidity, the water absorption, and degradability. In this study, an evaluation of the proliferation and differentiation of mesenchymal stem cells of the bone marrow in a hydrogel composed of type I collagen-hyaluronic acid was performed. An examination of the repair capacity of cartilage in vivo in the presence of TGF-B1 was also performed. The results of this research suggest a wide range of collagen applications in the biomedical field. This hydrogel system showed high biocompatibility, supported the chondrogenic differentiation of mesenchymal stem cells in the bone marrow, and allowed appropriate hyaline cartilage repair.

Table 5. Cartilage tissue regeneration.

\begin{tabular}{|c|c|c|c|c|c|}
\hline Form & Origin & $\begin{array}{l}\text { Extraction } \\
\text { technique }\end{array}$ & $\begin{array}{l}\text { Biological } \\
\text { evaluation }\end{array}$ & Results & References \\
\hline $\begin{array}{l}\text { Collagen } \\
\text { peptide }\end{array}$ & $\begin{array}{l}\text { Skin of deepwater ocean } \\
\text { fish (cod, haddock, and } \\
\text { pollock) }\end{array}$ & $\begin{array}{l}\text { Enzymatic } \\
\text { hydrolysis }\end{array}$ & $\begin{array}{l}\text { Horse adipose- } \\
\text { derived stromal cells }\end{array}$ & $\begin{array}{l}\text { Increased } \\
\text { glycosaminoglycan } \\
\text { expression } \\
\text { Induced chondrogenic } \\
\text { differentiation } \\
\end{array}$ & [108] \\
\hline $\begin{array}{l}\text { Collagen } \\
\text { peptide }\end{array}$ & $\begin{array}{l}\text { Skins of Gadiformes } \\
\text { species }\end{array}$ & $\begin{array}{l}\text { Enzymatic } \\
\text { hydrolysis }\end{array}$ & $\begin{array}{l}\text { Rabbit osteoarthritis } \\
\text { model in vivo }\end{array}$ & $\begin{array}{l}\text { Chondroprotective } \\
\text { effects }\end{array}$ & [103] \\
\hline Scaffold & $\begin{array}{l}\text { Jellyfish } \\
\text { sculentum }\end{array}$ & $\begin{array}{l}\text { Freeze-drying } \\
\text { EDC cross-linked }\end{array}$ & $\begin{array}{l}\text { Primary human and } \\
\text { rat nasal septum } \\
\text { chondrocytes } \\
\text { Rat septal cartilage } \\
\text { defect model in vivo } \\
\end{array}$ & $\begin{array}{l}\text { Promoted adhesion and } \\
\text { cartilaginous matrix } \\
\text { proteins production } \\
\text { Reduced nasal septum } \\
\text { perforations }\end{array}$ & [102] \\
\hline $\begin{array}{l}\text { Collagen } \\
\text { solution }\end{array}$ & $\begin{array}{lll}\begin{array}{l}\text { Tilapia } \\
\text { collagen }\end{array} & \text { fish } & \text { scale } \\
\end{array}$ & $\begin{array}{l}\text { Acid soluble } \\
\text { collagen isolation } \\
\text { method }\end{array}$ & $\begin{array}{l}\text { Human } \\
\text { mesenchymal stem } \\
\text { cells }\end{array}$ & $\begin{array}{l}\text { Enhanced chondrogenic } \\
\text { differentiation } \\
\text { Elevated expression of } \\
\text { chondrogenic markers } \\
\text { Increased } \\
\text { glycosaminoglycan } \\
\text { expression }\end{array}$ & [104] \\
\hline Scaffold & $\begin{array}{ll}\text { Jellyfish } & \text { Rhopilemae } \\
\text { sculentum } & \end{array}$ & $\begin{array}{l}\text { Freeze-drying } \\
\text { EDC cross-linked }\end{array}$ & $\begin{array}{lr}\text { Primary human } \\
\text { mesenchymal stem } \\
\text { cells }\end{array}$ & $\begin{array}{l}\text { Induced chondrogenic } \\
\text { differentiation }\end{array}$ & [105] \\
\hline Cryogel & $\begin{array}{l}\text { Blue shark } \\
\text { (Prionaceglauca) } \text { skin }\end{array}$ & $\begin{array}{l}\text { Cryogelation } \\
\text { EDC cross-linked }\end{array}$ & $\begin{array}{l}\text { Human adipose } \\
\text { stem cells }\end{array}$ & $\begin{array}{l}\text { Promoted chondrogenic } \\
\text { cell differentiation }\end{array}$ & [106] \\
\hline Scaffold & Not reported & Freeze-drying & $\begin{array}{l}\text { Articular } \begin{array}{r}\text { cartilage } \\
\text { lesion } \\
\text { modthotopic }\end{array} \\
\end{array}$ & $\begin{array}{l}\text { Induced the formation of } \\
\text { fibrous tissue } \\
\text { Replaced the scaffold } \\
\text { with the newly formed } \\
\text { cartilage-like tissue } \\
\text { Displayed the } \\
\text { expression of typical } \\
\text { cartilage markers }\end{array}$ & [109] \\
\hline Hydrogel & Not reported & $\begin{array}{l}\text { Freeze-drying } \\
\text { EDC and NHS } \\
\text { cross-linked }\end{array}$ & $\begin{array}{l}\text { Rat bone marrow } \\
\text { mesenchymal stem } \\
\text { cell } \\
\text { Cartilage defect } \\
\text { model in vivo }\end{array}$ & $\begin{array}{l}\text { Promoted chondrogenic } \\
\text { cell differentiation with } \\
\text { a great biocompatibility } \\
\text { Induced good hyaline } \\
\text { cartilage repair }\end{array}$ & [110] \\
\hline
\end{tabular}

3.1.6. Corneal tissue regeneration.

The healthy cornea is a tough, transparent anterior surface of the eye that is essential for visual acuity. Corneal damage is a major cause of vision disturbances leading to limbal stem cell deficiency. To this end, several therapeutic strategies are being developed to treat limbal stem cell deficiency (Table 6). Indeed, Krishnanet and colleagues developed (in vitro) a novel source of collagen from fish scales (Latescalcarifer) to develop the biocompatible 
scaffold for culturing limbal stem cells, which perfectly replace the human amniotic membrane [36]. An evaluation of fish scales' physicochemical, mechanical, and cultural characteristics was compared to the denuded human amniotic membrane. Furthermore, cultured corneal cells were characterized by an RT-PCR for putative stem cell markers. This study showed that collagen's mechanical and physical forces derived from fish scales were good enough to be manipulated relative to the human amniotic membrane. Observation under a light microscope showed epithelial migration after $48 \mathrm{~h}$ from limbal explants plated on collagen isolated from fish scales and on the human amniotic membrane after $72 \mathrm{~h}$. At the end of the $15^{\text {th }}$ day, confluent growth comparable to the morphological characteristics of the limbal epithelium was recorded. Also, the collagenase assay, assessment of swelling rate, and microbial resistance of fish scales gave better results than the human amniotic membrane. In summary, this study has shown that collagen derived from fish scales ( $L$. calcarifer) can be used as a new material in corneal tissue engineering. Another study in rat models demonstrated the fish scale-derived collagen matrix's potential as an alternative for human donor corneal tissue [111]. Indeed, several parameters were measured, namely the diffusion and the transmission of the light from the collagen matrix derived from fish scales and their comparison with those of the cornea human. The short-term biocompatibility of this collagen matrix was also tested in this in vivo model.

The measurement of light scattering was performed using a stray light meter, and light transmission was measured using a broadband absorption spectrometer.

To examine biocompatibility, three methods were adopted; implantation of the collagen matrix derived from fish scales in anterior lamellar keratoplasty, its placement in an interlamellar and subconjunctival corneal pocket.

Transparency, neovascularization, and epithelial lesions were monitored for 21 days. Cell morphology and infiltration were evaluated histologically.

The preliminary results demonstrated that the amount of light scattered was comparable to that seen in early cataracts. The percentage of light transmission was similar to the transmission through the human cornea. The results of light scattering and transmission data showed that the early version of this fish scale-derived collagen matrix was comparable to human corneal tissue in this regard.

Histological examination showed chronic inflammation varying from mild to moderate in the anterior lamellar keratoplasty group and the interlamellar corneal pocket to severe in the subconjunctival group. Despite the technical difficulties, it was possible to use the collagen matrix derived from fish scales for anterior lamellar keratoplasty, while the placement of an interlamellar corneal pocket led to the fusion of the anterior lamella. Therefore, further studies are needed to understand its immunogenicity better.

Table 6. Corneal tissue regeneration.

\begin{tabular}{|c|c|c|c|c|c|}
\hline Form & Origin & $\begin{array}{l}\text { Extraction } \\
\text { technique }\end{array}$ & $\begin{array}{l}\text { Biological } \\
\text { evaluation }\end{array}$ & Results & References \\
\hline $\begin{array}{l}\text { Native } \\
\text { collagen }\end{array}$ & $\begin{array}{l}\text { Fish } \\
\text { (Latescalcarifer)scales }\end{array}$ & Drying at $25^{\circ} \mathrm{C}$ & $\begin{array}{l}\text { Primary human } \\
\text { limbal epithelial } \\
\text { cells }\end{array}$ & $\begin{array}{l}\text { Enhanced cell viability, } \\
\text { growth, proliferation, } \\
\text { and migration } \\
\text { Recorded a good } \\
\text { swelling ratio and } \\
\text { microbial resistance }\end{array}$ & [36] \\
\hline Scaffold & $\begin{array}{l}\text { Tilapia fish scale-derived } \\
\text { collagen matrix }\end{array}$ & $\begin{array}{l}\text { Decellularization } \\
\text { Decalcification }\end{array}$ & $\begin{array}{l}\text { Rat ocular } \\
\text { implantation } \\
\text { model in vivo }\end{array}$ & $\begin{array}{l}\text { Biocompatible } \\
\text { Adequate light } \\
\text { transmission } \\
\text { Reasonable light- } \\
\text { scattering values }\end{array}$ & [111] \\
\hline
\end{tabular}




\subsubsection{Dental tissue regeneration.}

It has been reported that collagen has also proven a key role in dental tissue regeneration (Table 7). Indeed, different forms of collagen extracted by several techniques of extractions have shown their capacity to induce dental tissue regeneration, and therefore they can be used in biomedical applications to regenerate dental tissue [112-118]. Collagen peptide extracted from Tilapia scale using enzymatical hydrolysis was tested Rat odontoblast-like cell line [112] and human periodontal ligament cells [113]. The results showed that collagen improves cellular attachment and viability by up-regulation of gene expression and accelerating matrix mineralization [112]. Collagen also promoted cell viability and up-regulated gene expression of proteins of human periodontal ligament cells [113]. Moreover, collagen peptide extracted from Tilapia fish skin collagen type I by Freeze-drying showed an important capacity to enhance the level of osteocalcin secretion towards osteogenic differentiation in human periodontal ligament fibroblasts [115]. It was recently reported that collagen gel extracted from the dermis of market-weight pigs by polymerization exhibits a positive effect on dental tissue regeneration by secretion growth factors, promoting cell differentiation, and induced endothelial and osteogenic cell proliferation [116].

Table 7. Dental tissue regeneration.

\begin{tabular}{|c|c|c|c|c|c|}
\hline Form & Origin & $\begin{array}{l}\text { Extraction } \\
\text { technique }\end{array}$ & $\begin{array}{l}\text { Biological } \\
\text { evaluation }\end{array}$ & Results & References \\
\hline $\begin{array}{l}\text { Collagen } \\
\text { peptide }\end{array}$ & $\begin{array}{l}\text { Tilapia scale } \\
\text { derived type } \\
\text { I collagen }\end{array}$ & $\begin{array}{l}\text { Enzymatical } \\
\text { hydrolysis }\end{array}$ & $\begin{array}{l}\text { Rat odontoblast- } \\
\text { like cell line }\end{array}$ & $\begin{array}{l}\text { Increased initial cell } \\
\text { attachment and cell viability } \\
\text { Up-regulated osteogenic gene } \\
\text { expression } \\
\text { Accelerated } \\
\text { mineralization }\end{array}$ & [112] \\
\hline $\begin{array}{l}\text { Collagen } \\
\text { peptide }\end{array}$ & $\begin{array}{l}\text { Tilapia } \\
\text { scales }\end{array}$ & $\begin{array}{l}\text { Enzymatical } \\
\text { hydrolysis }\end{array}$ & $\begin{array}{l}\text { Human } \\
\text { periodontal } \\
\text { ligament cells }\end{array}$ & $\begin{array}{l}\text { Promoted cell viability } \\
\text { Up-regulated the expression of } \\
\text { osteogenic markers } \\
\text { Up-regulated the production of } \\
\text { osteogenic-related proteins }\end{array}$ & [113] \\
\hline Scaffold & $\begin{array}{l}\text { Tilapia fish } \\
\text { collagen }\end{array}$ & Elecrospinning & $\begin{array}{l}\text { Human } \\
\text { periodontal } \\
\text { ligament cells } \\
\text { A dog class II } \\
\text { furcation defect } \\
\text { model in vivo }\end{array}$ & $\begin{array}{l}\text { Enhanced cell viability and } \\
\text { osteogenic gene expression } \\
\text { Promoted the expression of } \\
\text { RUNX-2 and OPN protein } \\
\text { Promoted bone regeneration }\end{array}$ & [114] \\
\hline $\begin{array}{l}\text { Collagen } \\
\text { peptide }\end{array}$ & $\begin{array}{l}\text { Tilapia fish } \\
\text { skin collagen } \\
\text { type I }\end{array}$ & Freeze-drying & $\begin{array}{l}\text { Human } \\
\text { periodontal } \\
\text { ligament } \\
\text { fibroblasts }\end{array}$ & $\begin{array}{l}\text { Enhanced the level of } \\
\text { osteocalcin secretion towards } \\
\text { osteogenic differentiation }\end{array}$ & [115] \\
\hline $\begin{array}{l}\text { Collagen } \\
\text { gel }\end{array}$ & $\begin{array}{l}\text { Dermis of } \\
\text { market- } \\
\text { weight pigs }\end{array}$ & Polymerization & $\begin{array}{ll}\text { Dental } & \text { pulp } \\
\text { stem cells }\end{array}$ & $\begin{array}{l}\text { Released growth factors } \\
\text { Promoted cell differentiation } \\
\text { Induced endothelial and } \\
\text { osteogenic differentiation }\end{array}$ & [116] \\
\hline
\end{tabular}

\subsubsection{Other applications.}

Fibroblasts allow collagen to have dual functionality by ensuring the cohesion of tissues and organs via elastin and glycoproteins. On the other hand, by giving these tissues properties of flexibility, hydration, and resistance. In addition to the regeneration of the various tissues mentioned above, these properties have enabled collagen to be used in other applications.

Indeed, marine collagen has also been used in the food and agricultural industry by Prashant et al. [119] where they isolated and characterized acid-soluble collagen (ASC) from carp (Cyprinuscarpio) scales. Initially, the researchers aimed to produce paneer (a dairy product) by incorporating the extracted collagen. In the second part of the experiment, they 
tested the ability of metabolites released (enzymatically treated) from the scales to promote root growth and seed germination of Vignaradiata. Therefore, the prepared paneer showed high acceptability with good textural and sensorial characteristics. Also, the metabolites released promoted plant growth, allowing them to be used as a nitrogen fertilizer source for plants.

Moreover, three-dimensional (3D) cell culture systems constitute a fundamental means for several biomedical studies (in vitro and clinical). Additionally, scaffolding presents a major tool in cell support (biocompatibility and mechanical strength) for 3D cell culture and tissue engineering. In this regard, Choi and colleagues fabricated a novel nanofiber scaffold composed of a mixture of fish scale collagen and polycaprolactone using the electrospinning technique [61].

These scaffolds were characterized by analyzing fiber diameter distribution and their biocompatibility using mouse thymic epithelial cells via the evaluation of several parameters such as adhesion, proliferation, spreading, and gene/protein expression. Therefore, the fabricated scaffolds favored these parameters by stimulating the expression of genes involved in cell adhesion and thymopoiesis molecules. Thus, these scaffolds can be an ideal model of 3D cell culture.

Otherwise, collagen can act as a hemostatic agent in the case of massive uncontrolled hemorrhages. The body's natural mechanism is not always able to control abundant hemorrhages. Thereby, several studies have proven the effectiveness of collagen in regulating hemostasis[120,56] through the formation of platelet aggregates [121], the release of clotting factors, and the stimulation of platelets. In 2017, Cheng and collaborators extracted collagen from the jellyfish species Rhopilema esculentum, subsequently preparing a collagen sponge whose hemostatic ability was assessed by rat-tail amputation and whole-blood clotting experiments [122]. Consequently, the collagen sponges activated the hemostatic mechanism through physical absorption. Also, their application to experimental models of amputated rattails experiment reduced hemostasis time and bleeding; this may be attributed to the high rate of water absorption and the porous structure of collagen sponge.

Furthermore, myocardial tissue engineering constitutes a major tool for restoring and improving the functions of a diseased myocardium, hence developing suitable biomaterials for scaffolds supporting cardiomyocytes' properties. For this reason, several studies have chosen to evaluate natural polymers (collagen, gelatin, chitosan...). However, collagen application alone may present certain limitations for the scaffold (poor mechanical properties and accelerated degradation). In order to overcome these limitations, Fang et al. [123] incorporated chitosan with collagen for myocardial tissue engineering. For in vivo implantation, this collagen/chitosan composite scaffold requires stabilization by cross-linking to increase its strength further. Indeed, the authors comparatively studied three chemical cross-linking agents, namelygenip in (GP), glutaraldehyde (GTA), and tripolyphosphate (TPP). They found, as a result, high porosity (> 65\%) for all scaffold groups with excellent mechanical properties for TPP cross-linked scaffolds. In addition, TPP and GP cross-linked scaffolds recorded the best biocompatibility compared to GTA cross-linked scaffolds. Also, cardiomyocytes in TPP crosslinked scaffolds showed the best contractile performance. This indicates that TPP presents the most suitable cross-linking agent for collagen/chitosan scaffolding in myocardial tissue engineering.

Regarding vocal fold tissue engineering, Walimbe et al. [124] evaluated four types of hydrogels (having tunable viscoelastic characteristics), incorporated with fibrillar type I collagen and type III collagen, for their biocompatibility, bioavailability, and influence on 
vocal fold fibroblasts. Effectively, collagen's incorporation has significantly increased the mechanical properties of hydrogels, with better cell fixation and adhesion, creating a tissue microenvironment leading to remodeling.

Moreover, developing a novel source of collagen material has always been a major challenge in medical tissue engineering [125-127]. Indeed, Li et al. [128] chose aquatic collagen as an alternative to mammalian collagen. They isolated ASC and PSC (pepsin-soluble collagen) from the skin of tilapia (Oreochromisniloticus) in order to investigate their physicochemical and structural properties. Both collagens were characterized as type I collagen. In addition, they constructed tilapia skin collagen scaffolds that were implanted beneath the dorsal tissue of mice for tissue regeneration, using bovine collagen scaffolds as a control. As a result, the grafted scaffolds completely degraded without any inflammatory reaction, indicating their high biocompatibility and stability in vivo.

\section{Conclusions and Perspectives}

Collagen is a key substance for cells living and plays an important role in cellular and tissular homeostasis. In this review, it was reported that several natural resources could contain this substance, which possesses numerous physicochemical characteristics depending on the type of collagen. Importantly, several biomedical investigations showed that this molecule exhibits important pharmacological effects, particularly on the regeneration of different tissue. Therefore, this molecule can be introduced to medical benefit after further pharmacodynamic and pharmacokinetic investigations for its validation.

\section{Funding}

This research received no external funding.

\section{Acknowledgments}

This research has no acknowledgment.

\section{Conflicts of Interest}

The authors declare no conflict of interest.

\section{References}

1. Narayanan, N.; Calve, S. Extracellular Matrix at the Muscle - Tendon Interface: Functional Roles, Techniques to Explore and Implications for Regenerative Medicine. Connective Tissue Research 2021, 62, 53-71, https://doi.org/10.1080/03008207.2020.1814263.

2. Neff, L.S.; Bradshaw, A.D. Cross Your Heart? Collagen Cross-Links in Cardiac Health and Disease. Cellular Signalling 2021, 79, https://doi.org/10.1016/j.cellsig.2020.109889.

3. Martínez, M. A. R.; Galisteo, S. P.; Castán, H.; Hernández, M. E. M. Role of Proteoglycans on Skin Ageing: A Review. International Journal of Cosmetic Science 2020, 42, 529-535, https://doi.org/10.1111/ics.12660.

4. Tiplea, M.G.; Lemnaru, G.M.; Trușcă, R.D.; Holban, A.; Kaya, M.G.A.; Dragu, L.D.; Ficai, A.; Bleotu, C. Antimicrobial Films Based on Chitosan, Collagen, and $\mathrm{ZnO}$ for Skin Tissue Regeneration. Biointerface Res Appl Chem 2021, 11, 11985-11995,https://doi.org/10.33263/BRIAC114.1198511995.

5. Brodsky, B.; Eikenberry, E.F.; Belbruno, K.C.; Sterling, K. Variations in collagen fibril structure in tendons. Biopolymers 1982, 21, 935-951, https://doi.org/10.1002/bip.360210507.

6. Xiong, X. New Insights into Structure and Function of Type I Collagen. Neuer Einblick in die Struktur und Funktion des Typ I-Kollagens 2008, https://doi.org/10.18419/opus-1773.

7. Copes, F.; Pien, N.; Van Vlierberghe, S.; Boccafoschi, F.; Mantovani, D. Collagen-Based Tissue Engineering Strategies for Vascular Medicine. Front Bioeng Biotechnol 2019, 7, https://doi.org/10.3389/fbioe.2019.00166. 
8. Miller, E.J.; Kent Rhodes, R. [2] Preparation and Characterization of the Different Types of Collagen. In: Methods in Enzymology. Structural and Contractile Proteins Part A: Extracellular Matrix; Academic Press, Volume 82, 1982; pp 33-64; https://doi.org/10.1016/0076-6879(82)82059-4.

9. Lin, K.; Zhang, D.; Macedo, M.H.; Cui, W.; Sarmento, B.; Shen, G. Advanced Collagen-Based Biomaterials for Regenerative Biomedicine. Advanced Functional Materials 2019, 29, https://doi.org/10.1002/adfm.201804943.

10. Glowacki, J.; Mizuno, S. Collagen scaffolds for tissue engineering. Biopolymers 2008, 89, 338-344, https://doi.org/10.1002/bip.20871.

11. Krane, S. M. The importance of proline residues in the structure, stability and susceptibility to proteolytic degradation of collagens . Amino acids 2008, 35(4), 703.

12. Chan, W.W.; Yeo, D.C.; Tan, V.; Singh, S.; Choudhury, D.; Naing, M.W. Additive Biomanufacturing with Collagen Inks. Bioengineering 2020, 7, https://doi.org/10.3390/bioengineering7030066.

13. Kuznetsova, N.; Leikin, S. Does the Triple Helical Domain of Type I Collagen Encode Molecular Recognition and Fiber Assembly while Telopeptides Serve as Catalytic Domains?: Effect Of Proteolytic Cleavage On Fibrillogenesis And On Collagen-Collagen Interaction In Fibers*. Journal of Biological Chemistry 1999, 274, 36083-36088, https://doi.org/10.1074/jbc.274.51.36083.

14. Wohllebe, M.; Carmichael, D.J. Type-I Trimer and Type-I Collagen in Neutral-Salt-Soluble Lathyritic-Rat Dentine. European Journal of Biochemistry 1978, 92, 183-188, https://doi.org/10.1111/j.14321033.1978.tb12736.x.

15. ИГНАТЬЕВА; АВЕРКИЕВ. ОПРЕДЕЛЕНИЕ ГИДРОКСИПРОЛИНА В ТКАНЯХ И ОЦЕНКА СОДЕРЖАНИЯ В НИХ КОЛЛАГЕНА https://elibrary.ru/item.asp?id=9479410 (accessed Jan 3, 2021).

16. Sanz, B.; Albillos Sanchez, A.; Tangey, B.; Gilmore, K.; Yue, Z.; Liu, X.; Wallace, G. Light Cross-Linkable Marine Collagen for Coaxial Printing of a 3D Model of Neuromuscular Junction Formation. Biomedicines 2021, 9, https://doi.org/10.3390/biomedicines9010016.

17. Gharagheshlagh, S.; Fatemi, M.J.; Jamili, S.; Nourani, A.M.; Nourani, M.R. Isolation and Characterization of Acid-Soluble Collagen from the Skin of Rutilus Frisii Kutum (Kamensky) of the Caspian Sea. Iranian Journal of Fisheries Sciences 2020, 19, 768-779.

18. Oliveira, V.d.M.; Assis, C.R.D.; Costa, B.d.A.M.; Neri, R.C.d.A.; Monte, F.T.D.; Freitas, H.M.S.d.C.V.; França, R.C.P.; Santos, J.F.; Bezerra, R.d.S.; Porto, A.L.F. Physical, biochemical, densitometric and spectroscopic techniques for characterization collagen from alternative sources: A review based on the sustainable valorization of aquatic by-products. Journal of Molecular Structure 2021, 1224, https://doi.org/10.1016/j.molstruc.2020.129023.

19. Wang, B.; Wang, Y.-M.; Chi, C.-F.; Luo, H.-Y.; Deng, S.-G.; Ma, J.-Y. Isolation and Characterization of Collagen and Antioxidant Collagen Peptides from Scales of Croceine Croaker (Pseudosciaena crocea). Marine Drugs 2013, 11, 4641-4661, https://doi.org/10.3390/md11114641.

20. Blidi, O.; Elomari, N.; Kamar-Zaman, Y.; Chakir, I.; Ali Abdou, K.; Lebjar, N.; Ibrahimi, A.; Chokairi, O.; Barkiyou, M. Simplified Extraction and Characterization of Acetic Acid Solubilized Type I Collagen Derived from Solea Solea Skin and Wistar Rat Tails for Biomedical and Biotechnological Applications. Journal of Chemical and Pharmaceutical Research 2017, 2017, 154-164.

21. Liu, W.; Li, G.; Miao, Y.; Wu, X. Preparation and Characterization of Pepsin-Solubilized Type I Collagen from the Scales of Snakehead (Ophiocephalus Argus). Journal of Food Biochemistry 2009, 33, 20-37, https://doi.org/10.1111/j.1745-4514.2008.00207.x.

22. Sankar, S.; Sekar, S.; Mohan, R.; Rani, S.; Sundaraseelan, J.; Sastry, T.P. Preparation and partial characterization of collagen sheet from fish (Lates calcarifer) scales. International Journal of Biological Macromolecules 2008, 42, 6-9, https://doi.org/10.1016/j.ijbiomac.2007.08.003.

23. Kim, J.S.; Park, J.W. Partially Purified Collagen from Refiner Discharge of Pacific Whiting Surimi Processing. Journal of Food Science 2005, 70, c511-c516, https://doi.org/10.1111/j.13652621.2005.tb11510.x.

24. Shanmugam, V.; Ramasamy, P.; Subhapradha, N.; Sudharsan, S.; Seedevi, P.; Moovendhan, M.; K, J.; Shanmugam, A.; Srinivasan, A. Extraction, structural and physical characterization of type I collagen from the outer skin of Sepiella inermis (Orbigny, 1848). African Journal Of Biotechnology 2012, 11, 1432614337, https://doi.org/10.4314/ajb.v11i78.

25. Rigo, C.; Hartmann, D.J.; Bairati, A. Electrophoretic and immunochemical study of collagens from Sepia officinalis cartilage. Biochimica et Biophysica Acta (BBA) - General Subjects 2002, 1572, 77-84, https://doi.org/10.1016/S0304-4165(02)00280-5.

26. Nagai, T. Collagen from Diamondback Squid (Thysanoteuthis rhombus) Outer Skin. Zeitschrift für Naturforschung C 2004, 59, 271-275, https://doi.org/10.1515/znc-2004-3-426.

27. Kiew, P.L.; Mat Don, M. The Influence of Acetic Acid Concentration on the Extractability of Collagen from the Skin of Hybrid Clarias Sp. and Its Physicochemical Properties: A Preliminary Study. Focusing on Modern Food Industry (FMFI) 2013, 2, 123-128.

28. Pozzolini, M.; Scarfi, S.; Giovine, M. Marine Collagen and Its Biotechnological Applications. In: Encyclopedia of Marine Biotechnology. John Wiley \& Sons, Ltd, 2020; pp 1007-1030, https://doi.org/10.1002/9781119143802.ch39. 
29. Sato, K.; Yoshinaka, R.; Sato, M.; Itoh, Y.; Shimizu, Y. Isolation of types I and V collagens from carp muscle. Comparative Biochemistry and Physiology Part B: Comparative Biochemistry 1988, 90, 155-158, https://doi.org/10.1016/0305-0491(88)90053-3.

30. Ikoma, T.; Kobayashi, H.; Tanaka, J.; Walsh, D.; Mann, S. Physical properties of type I collagen extracted from fish scales of Pagrus major and Oreochromis niloticas. International Journal of Biological Macromolecules 2003, 32, 199-204, https://doi.org/10.1016/S0141-8130(03)00054-0.

31. Ogawa, M.; Portier, R.J.; Moody, M.W.; Bell, J.; Schexnayder, M.A.; Losso, J.N. Biochemical properties of bone and scale collagens isolated from the subtropical fish black drum (Pogonia cromis) and sheepshead seabream (Archosargus probatocephalus). Food Chemistry 2004, 88, 495-501, https://doi.org/10.1016/j.foodchem.2004.02.006.

32. Nishimoto, M.; Sakamoto, R.; Mizuta, S.; Yoshinaka, R. Identification and characterization of molecular species of collagen in ordinary muscle and skin of the Japanese flounder Paralichthys olivaceus. Food Chemistry 2005, 90, 151-156, https://doi.org/10.1016/j.foodchem.2004.03.034.

33. Hwang, J.-H.; Mizuta, S.; Yokoyama, Y.; Yoshinaka, R. Purification and characterization of molecular species of collagen in the skin of skate (Raja kenojei). Food Chemistry 2007, 100, 921-925, https://doi.org/10.1016/j.foodchem.2005.10.046.

34. Hoseinie, S.H.; Ataei, M.; Mikaeil, R. Effects of microfabric on drillability of rocks. Bulletin of Engineering Geology and the Environment 2019, 78, 1443-1449, https://doi.org/10.1007/s10064-017-1188-z.

35. Wang, L.; An, X.; Xin, Z.; Zhao, L.; Hu, Q. Isolation and Characterization of Collagen from the Skin of Deep-Sea Redfish (Sebastes mentella). Journal of Food Science 2007, 72, E450-E455, https://doi.org/10.1111/j.1750-3841.2007.00478.x.

36. Krishnan, S.; Sekar, S.; Katheem, M.F.; Krishnakumar, S.; Sastry, T.P. Fish Scale Collagen-A Novel Material for Corneal Tissue Engineering. Artificial Organs 2012, 36, 829-835, https://doi.org/10.1111/j.1525-1594.2012.01452.x.

37. Zhang, J.; Duan, R.; Ye, C.; Konno, K. Isolation and Characterization of Collagens from Scale of Silver Carp (Hypophthalmichthys Molitrix). Journal of Food Biochemistry 2010, 34, 1343-1354, https://doi.org/10.1111/j.1745-4514.2010.00439.x.

38. Duan, R.; Zhang, J.; Du, X.; Yao, X.; Konno, K. Properties of Collagen from Skin, Scale and Bone of Carp (Cyprinus Carpio). Food Chemistry 2009, 112, 702-706, https://doi.org/10.1016/j.foodchem.2008.06.020.

39. Nagai, T.; Suzuki, N. Isolation of Collagen from Fish Waste Material — Skin, Bone and Fins. Food Chemistry 2000, 68, 277-281, https://doi.org/10.1016/S0308-8146(99)00188-0.

40. Wang, L.; An, X.; Yang, F.; Xin, Z.; Zhao, L.; Hu, Q. Isolation and Characterisation of Collagens from the Skin, Scale and Bone of Deep-Sea Redfish (Sebastes Mentella). Food Chemistry 2008, 108, 616-623, https://doi.org/10.1016/j.foodchem.2007.11.017.

41. Pati, F.; Adhikari, B.; Dhara, S. Isolation and Characterization of Fish Scale Collagen of Higher Thermal Stability. Bioresource Technology 2010, 101, 3737-3742, https://doi.org/10.1016/j.biortech.2009.12.133.

42. Nagai, T.; Worawattanamateekul, W.; Suzuki, N.; Nakamura, T.; Ito, T.; Fujiki, K.; Nakao, M.; Yano, T. Isolation and Characterization of Collagen from Rhizostomous Jellyfish (Rhopilema Asamushi). Food Chemistry 2000, 70, 205-208, https://doi.org/10.1016/S0308-8146(00)00081-9.

43. Nagai, T.; Araki, Y.; Suzuki, N. Collagen of the Skin of Ocellate Puffer Fish (Takifugu Rubripes). Food Chemistry 2002, 78, 173-177, https://doi.org/10.1016/S0308-8146(01)00396-X.

44. Rigby, B.J. Amino-Acid Composition and Thermal Stability of the Skin Collagen of the Antarctic Ice-Fish. Nature 1968, 219, 166-167, https://doi.org/10.1038/219166a0.

45. Wong, D. Mechanism and Theory in Food Chemistry. Second Edition; Springer Link, 2018; https://doi.org/10.1007/978-3-319-50766-8.

46. Piez, K.A.; Gross, J. The Amino Acid Composition of Some Fish Collagens: The Relation between Composition and Structure. J Biol Chem 1960, 235, 995-998.

47. Gustavson, K.H. The Function of Hydroxyproline in Collagens. Nature 1955, 175, 70-74, https://doi.org/10.1038/175070a0.

48. Luo, J.; Yang, X.; Cao, Y.; Li, G.; Meng, Y.; Li, C. Structural Characterization and in Vitro Immunogenicity Evaluation of Amphibian-Derived Collagen Type II from the Cartilage of Chinese Giant Salamander (Andrias Davidianus). Journal of Biomaterials Science, Polymer Edition 2020, 31, 1941-1960, https://doi.org/10.1080/09205063.2020.1786882.

49. Zou, Y.; Yang, H.; Zhang, X.; Xu, P.; Jiang, D.; Zhang, M.; Xu, W.; Wang, D. Effect of Ultrasound Power on Extraction Kinetic Model, and Physicochemical and Structural Characteristics of Collagen from Chicken Lung. Food Prod Process and Nutr 2020, 2, https://doi.org/10.1186/s43014-019-0016-1.

50. Gustavson, K.H. Chemistry and Reactivity of Collagen. 1956.

51. Xiong, Y.L. Structure-Function Relationships of Muscle Proteins. In: Food proteins and their applications. CRC Press, 2017; pp 341-392.

52. Terada, M.; Izumi, K.; Ohnuki, H.; Saito, T.; Kato, H.; Yamamoto, M.; Kawano, Y.; Nozawa-Inoue, K.; Kashiwazaki, H.; Ikoma, T.; Tanaka, J.; Maeda, T. Construction and Characterization of a Tissue-Engineered Oral Mucosa Equivalent Based on a Chitosan-Fish Scale Collagen Composite. Journal of Biomedical 
Materials Research Part B: Applied Biomaterials 2012, $100 B, \quad 1792-1802$, https://doi.org/10.1002/jbm.b.32746.

53. Tabatabaei, F.; Moharamzadeh, K.; Tayebi, L. Fibroblast Encapsulation in Gelatin Methacryloyl (GelMA) versus Collagen Hydrogel as Substrates for Oral Mucosa Tissue Engineering. Journal of Oral Biology and Craniofacial Research 2020, 10, 573-577, https://doi.org/10.1016/j.jobcr.2020.08.015.

54. Shang, Y.; Yao, S.; Qiao, X.; Wang, Z.; Zhao, X.; Huang, Z.; Gu, Q.; Wang, N.; Peng, C. Evaluations of Marine Collagen Peptides from Tilapia Skin on Experimental Oral Ulcer Model of Mice. Materials Today Communications 2020, https://doi.org/10.1016/j.mtcomm.2020.101893.

55. Blagushina, N.; Diachkova, E.; Volkova; Pankush, S.; Tarasenko, S. Comparative Analysis of the Use of Domestic Bioresorbable Collagen Membranes at the Closure of Postoperative Defects of the Oral Mucosa in an Experiment In Vivo. Biointerface Res Appl Chem 2021, 11, 98049812,https://doi.org/10.33263/BRIAC112.98049812.

56. Jeong, S.; Kim, S.Y.; Cho, S.K.; Chong, M.S.; Kim, K.S.; Kim, H.; Lee, S.B.; Lee, Y.M. Tissue-Engineered Vascular Grafts Composed of Marine Collagen and PLGA Fibers Using Pulsatile Perfusion Bioreactors. Biomaterials 2007, 28, 1115-1122, https://doi.org/10.1016/j.biomaterials.2006.10.025.

57. Wang, J.K.; Yeo, K.P.; Chun, Y.Y.; Tan, T.T.Y.; Tan, N.S.; Angeli, V.; Choong, C. Fish Scale-Derived Collagen Patch Promotes Growth of Blood and Lymphatic Vessels in Vivo. Acta Biomaterialia 2017, 63, 246-260, https://doi.org/10.1016/j.actbio.2017.09.001.

58. Wang, Y.; Zhang, C.; Zhang, Q.; Li, P. Composite Electrospun Nanomembranes of Fish Scale Collagen Peptides/Chito-Oligosaccharides: Antibacterial Properties and Potential for Wound Dressing. Int J Nanomedicine 2011, 6, 667-676, https://doi.org/10.2147/IJN.S17547.

59. Zhang, Z.; Wang, J.; Ding, Y.; Dai, X.; Li, Y. Oral Administration of Marine Collagen Peptides from Chum Salmon Skin Enhances Cutaneous Wound Healing and Angiogenesis in Rats. Journal of the Science of Food and Agriculture 2011, 91, 2173-2179, https://doi.org/10.1002/jsfa.4435.

60. Muthukumar, T.; Aravinthan, A.; Sharmila, J.; Kim, N. S.; Kim, J.-H. Collagen/Chitosan Porous Bone Tissue Engineering Composite Scaffold Incorporated with Ginseng Compound K. Carbohydrate Polymers 2016, 152, 566-574, https://doi.org/10.1016/j.carbpol.2016.07.003.

61. Chandika, P.; Ko, S.-C.; Oh, G.-W.; Heo, S.-Y.; Nguyen, V.-T.; Jeon, Y.-J.; Lee, B.; Jang, C.H.; Kim, G.; Park, W.S.; Chang, W.; Choi, I.-W.; Jung, W.-K. Fish Collagen/Alginate/Chitooligosaccharides Integrated Scaffold for Skin Tissue Regeneration Application. International Journal of Biological Macromolecules 2015, 81, 504-513, https://doi.org/10.1016/j.ijbiomac.2015.08.038.

62. Wang, J.; Xu, M.; Liang, R.; Zhao, M.; Zhang, Z.; Li, Y. Oral Administration of Marine Collagen Peptides Prepared from Chum Salmon (Oncorhynchus Keta) Improves Wound Healing Following Cesarean Section in Rats. Food \& Nutrition Research 2015, 59, https://doi.org/10.3402/fnr.v59.26411.

63. Vigneswari, S.; Murugaiyah, V.; Kaur, G.; Khalil, H.P.S.A.; Amirul, A.A. Biomacromolecule Immobilization: Grafting of Fish-Scale Collagen Peptides onto Aminolyzed P(3HB- Co -4HB) Scaffolds as a Potential Wound Dressing. Biomed. Mater 2016, 11, https://doi.org/10.1088/1748-6041/11/5/055009.

64. Pal, P.; Srivas, P.K.; Dadhich, P.; Das, B.; Maity, P.P.; Moulik, D.; Dhara, S. Accelerating Full Thickness Wound Healing Using Collagen Sponge of Mrigal Fish (Cirrhinus Cirrhosus) Scale Origin. International Journal of Biological Macromolecules https://doi.org/10.1016/j.ijbiomac.2016.04.032.

65. Jana, P.; Mitra, T.; Selvaraj, T.K.R.; Gnanamani, A.; Kundu, P.P. Preparation of Guar Gum Scaffold Film Grafted with Ethylenediamine and Fish Scale Collagen, Cross-Linked with Ceftazidime for Wound Healing Application. Carbohydrate Polymers 2016, 153, 573-581, https://doi.org/10.1016/j.carbpol.2016.07.053.

66. Li, N.; Zhang, Z.-J.; Li, X.-J.; Li, H.-Z.; Cui, L.-X.; He, D.-L. Microcapsules Biologically Prepared Using Perilla Frutescens (L.) Britt. Essential Oil and Their Use for Extension of Fruit Shelf Life: Microcapsules Biologically Prepared Using Perilla Frutescens Essential Oil. J. Sci. Food Agric 2017, 98, 1033-1041, https://doi.org/10.1002/jsfa.8552.

67. Hu, Z.; Yang, P.; Zhou, C.; Li, S.; Hong, P. Marine Collagen Peptides from the Skin of Nile Tilapia (Oreochromis Niloticus): Characterization and Wound Healing Evaluation. Marine Drugs 2017, 15, https://doi.org/10.3390/md15040102.

68. Zhang, J.; Sun, Y.; Zhao, Y.; Wei, B.; Xu, C.; He, L.; Oliveira, C.L.P.; Wang, H. Centrifugation-Induced Fibrous Orientation in Fish-Sourced Collagen Matrices. Soft Matter 2017, 13, 9220-9228, https://doi.org/10.1039/C7SM01871A.

69. Zhou, T.; Sui, B.; Mo, X.; Sun, J. Multifunctional and Biomimetic Fish Collagen/Bioactive Glass Nanofibers: Fabrication, Antibacterial Activity and Inducing Skin Regeneration in Vitro and in Vivo. Int $J$ Nanomedicine 2017a, 12, 3495-3507, https://doi.org/10.2147/IJN.S132459.

70. Ullah, S.; Zainol, I.; Chowdhury, S.R.; Fauzi, M.B. Development of Various Composition Multicomponent Chitosan/Fish Collagen/Glycerin 3D Porous Scaffolds: Effect on Morphology, Mechanical Strength, Biostability and Cytocompatibility. International Journal of Biological Macromolecules 2018, 111, 158168, https://doi.org/10.1016/j.ijbiomac.2017.12.136. 
71. Pozzolini, M.; Millo, E.; Oliveri, C.; Mirata, S.; Salis, A.; Damonte, G.; Arkel, M.; Scarfì, S. Elicited ROS Scavenging Activity, Photoprotective, and Wound-Healing Properties of Collagen-Derived Peptides from the Marine Sponge Chondrosia Reniformis. Marine Drugs 2018, 16, https://doi.org/10.3390/md16120465.

72. Chen, J.; Gao, K.; Liu, S.; Wang, S.; Elango, J.; Bao, B.; Dong, J.; Liu, N.; Wu, W. Fish Collagen Surgical Compress Repairing Characteristics on Wound Healing Process In Vivo. Marine Drugs 2019, 17, https://doi.org/10.3390/md17010033.

73. Wang, C.-H.; Hsieh, D.-J.; Periasamy, S.; Chuang, C.-T.; Tseng, F.-W.; Kuo, J.-C.; Tarng, Y.-W. Regenerative Porcine Dermal Collagen Matrix Developed by Supercritical Carbon Dioxide Extraction Technology: Role in Accelerated Wound Healing. Materialia 2020, 9, https://doi.org/10.1016/j.mtla.2019.100576.

74. Lazurko, C.; Khatoon, Z.; Goel, K.; Sedlakova, V.; Eren Cimenci, C.; Ahumada, M.; Zhang, L.; Mah, T.-F.; Franco, W.; Suuronen, E.J.; Alarcon, E.I. Multifunctional Nano and Collagen-Based Therapeutic Materials for Skin Repair. ACS Biomater. Sci. Eng 2020, 6, 1124-1134, https://doi.org/10.1021/acsbiomaterials.9b01281.

75. Yang, C.; Dan, N.; You, W.; Huang, Y.; Chen, Y.; Yu, G.; Dan, W.; Wen, H. Modification of CollagenChitosan Membrane by Oxidation Sodium Alginate and in Vivo/ in Vitro Evaluation for Wound Dressing Application. International Journal of Polymer Analysis and Characterization 2019, 24, 619-629, https://doi.org/10.1080/1023666X.2019.1648637.

76. Abolgheit, S.; Abdelkader, S.; Aboushelib, M.; Omar, E.; Mehanna, R. Bone Marrow-Derived Mesenchymal Stem Cells and Extracellular Vesicles Enriched Collagen Chitosan Scaffold in Skin Wound Healing (a Rat Model). J Biomater Appl 2020, https://doi.org/10.1177/0885328220963920.

77. Cui, B.; Zhang, C.; Gan, B.; Liu, W.; Liang, J.; Fan, Z.; Wen, Y.; Yang, Y.; Peng, X.; Zhou, Y. CollagenTussah Silk Fibroin Hybrid Scaffolds Loaded with Bone Mesenchymal Stem Cells Promote Skin Wound Repair in Rats. Materials Science and Engineering: C 2020, 109, https://doi.org/10.1016/j.msec.2019.110611.

78. Ferrario, C.; Rusconi, F.; Pulaj, A.; Macchi, R.; Landini, P.; Paroni, M.; Colombo, G.; Martinello, T.; Melotti, L.; Gomiero, C.; Candia Carnevali, M.D.; Bonasoro, F.; Patruno, M.; Sugni, M. From Food Waste to Innovative Biomaterial: Sea Urchin-Derived Collagen for Applications in Skin Regenerative Medicine. Marine Drugs 2020, 18, https://doi.org/10.3390/md18080414.

79. Ge, B.; Wang, H.; Li, J.; Liu, H.; Yin, Y.; Zhang, N.; Qin, S. Comprehensive Assessment of Nile Tilapia Skin (Oreochromis Niloticus) Collagen Hydrogels for Wound Dressings. Marine Drugs 2020, 18, https://doi.org/10.3390/md18040178.

80. Sadeghi-Avalshahr, A.R.; Nokhasteh, S.; Molavi, A.M.; Mohammad-Pour, N.; Sadeghi, M. Tailored PCL Scaffolds as Skin Substitutes Using Sacrificial PVP Fibers and Collagen/Chitosan Blends. International Journal of Molecular Sciences 2020, 21, https://doi.org/10.3390/ijms21072311.

81. Tsai, S.-W.; Huang, S.-S.; Yu, W.-X.; Hsu, Y.-W.; Hsu, F.-Y. Collagen Scaffolds Containing Hydroxyapatite-CaO Fiber Fragments for Bone Tissue Engineering. Polymers 2020, 12, https://doi.org/10.3390/polym12051174.

82. Liu, H.; Lin, M.; Liu, X.; Zhang, Y.; Luo, Y.; Pang, Y.; Chen, H.; Zhu, D.; Zhong, X.; Ma, S. SelfAssembly/Mineralization for Bone Tissue Engineering. Bioactive Materials 2020, 15.

83. Nabavi, M.H.; Salehi, M.; Ehterami, A.; Bastami, F.; Semyari, H.; Tehranchi, M.; Nabavi, M.A.; Semyari, H. A Collagen-Based Hydrogel Containing Tacrolimus for Bone Tissue Engineering. Drug Deliv. and Transl. Res 2020, 10, 108-121, https://doi.org/10.1007/s13346-019-00666-7.

84. Jin, S.; Sun, F.; Zou, Q.; Huang, J.; Zuo, Y.; Li, Y.; Wang, S.; Cheng, L.; Man, Y.; Yang, F.; Li, J. Fish Collagen and Hydroxyapatite Reinforced Poly(Lactide- Co-Glycolide) Fibrous Membrane for Guided Bone Regeneration. Biomacromolecules 2019, 20 (5), 2058-2067. https://doi.org/10.1021/acs.biomac.9b00267.

85. Bernhardt, A.; Paul, B.; Gelinsky, M. Biphasic Scaffolds from Marine Collagens for Regeneration of Osteochondral Defects. Marine Drugs 2018, 16, https://doi.org/10.3390/md16030091.

86. Parisi, J.R.; Fernandes, K.R.; Avanzi, I.R.; Dorileo, B.P.; Santana, A.F.; Andrade, A.L.; Gabbai-Armelin, P.R.; Fortulan, C.A.; Trichês, E.S.; Granito, R.N.; Renno, A.C.M. Incorporation of Collagen from Marine Sponges (Spongin) into Hydroxyapatite Samples: Characterization and In Vitro Biological Evaluation. Mar Biotechnol 2019, 21, 30-37, https://doi.org/10.1007/s10126-018-9855-z.

87. Diogo, G.S.; López-Senra, E.L.; Pirraco, R.P.; Canadas, R.F.; Fernandes, E.M.; Serra, J.; Pérez-Martín, R.I.; Sotelo, C.G.; Marques, A.P.; González, P.; Moreira-Silva, J.; Silva, T.H.; Reis, R.L. Marine Collagen/Apatite Composite Scaffolds Envisaging Hard Tissue Applications. Marine Drugs 2018, 16, https://doi.org/10.3390/md16080269.

88. Mredha, M.T.I.; Kitamura, N.; Nonoyama, T.; Wada, S.; Goto, K.; Zhang, X.; Nakajima, T.; Kurokawa, T.; Takagi, Y.; Yasuda, K.; Gong, J.P. Anisotropic tough double network hydrogel from fish collagen and its spontaneous in vivo bonding to bone. Biomaterials 2017, 132, 85-95, https://doi.org/10.1016/j.biomaterials.2017.04.005.

89. Chamieh, F.; Collignon, A.-M.; Coyac, B.R.; Lesieur, J.; Ribes, S.; Sadoine, J.; Llorens, A.; Nicoletti, A.; Letourneur, D.; Colombier, M.-L.; Nazhat, S.N.; Bouchard, P.; Chaussain, C.; Rochefort, G.Y.Accelerated 
Craniofacial Bone Regeneration through Dense Collagen Gel Scaffolds Seeded with Dental Pulp Stem Cells. Sci Rep 2016, 6, https://doi.org/10.1038/srep38814.

90. Brennan, O.; Stenson, B.; Widaa, A.; O'Gorman, D.M.; O'Brien, F.J. Incorporation of the Natural Marine Multi-Mineral Dietary Supplement Aquamin Enhances Osteogenesis and Improves the Mechanical Properties of a Collagen-Based Bone Graft Substitute. Journal of the Mechanical Behavior of Biomedical Materials 2015, 47, 114-123, https://doi.org/10.1016/j.jmbbm.2015.03.015.

91. Xu, Y.; Han, X.; Li, Y. Effect of Marine Collagen Peptides on Long Bone Development in Growing Rats. J. Sci. Food Agric 2010, 90, 1485-1491, https://doi.org/10.1002/jsfa.3972.

92. Liu, C.; Sun, J. Potential Application of Hydrolyzed Fish Collagen for Inducing the Multidirectional Differentiation of Rat Bone Marrow Mesenchymal Stem Cells. Biomacromolecules 2014, 15, 436-443, https://doi.org/10.1021/bm401780v.

93. Yamada, S.; Yoshizawa, Y.; Kawakubo, A.; Ikeda, T.; Yanagiguchi, K.; Hayashi, Y. Early Gene and Protein Expression Associated with Osteoblast Differentiation in Response to Fish Collagen Peptides Powder. Dent. Mater. J 2013, 32, 233-240, https://doi.org/10.4012/dmj.2012-188.

94. Yamada, S.; Nagaoka, H.; Terajima, M.; Tsuda, N.; Hayashi, Y.; Yamauchi, M. Effects of Fish Collagen Peptides on Collagen Post-Translational Modifications and Mineralization in an Osteoblastic Cell Culture System. Dent. Mater. J 2013, 32, 88-95, https://doi.org/10.4012/dmj.2012-220.

95. Pati, F.; Datta, P.; Adhikari, B.; Dhara, S.; Ghosh, K.; Mohapatra, P.K.D. Collagen Scaffolds Derived from Fresh Water Fish Origin and Their Biocompatibility. J. Biomed. Mater. Res 2012, 100A, 1068-1079, https://doi.org/10.1002/jbm.a.33280.

96. Pallela, R.; Venkatesan, J.; Janapala, V.R.; Kim, S.-K. Biophysicochemical Evaluation of ChitosanHydroxyapatite-Marine Sponge Collagen Composite for Bone Tissue Engineering. J. Biomed. Mater. Res 2012, 100A, 486-495, https://doi.org/10.1002/jbm.a.33292.

97. Teixeira, S.; Fernandes, M.H.; Ferraz, M.P.; Monteiro, F.J. Proliferation and Mineralization of Bone Marrow Cells Cultured on Macroporous Hydroxyapatite Scaffolds Functionalized with Collagen Type I for Bone Tissue Regeneration. J. Biomed. Mater. Res 2010, 95A, 1-8, https://doi.org/10.1002/jbm.a.32600.

98. Matsumoto, R.; Uemura, T.; Xu, Z.; Yamaguchi, I.; Ikoma, T.; Tanaka, J. Rapid Oriented Fibril Formation of Fish Scale Collagen Facilitates Early Osteoblastic Differentiation of Human Mesenchymal Stem Cells 2015, 103, https://doi.org/10.1002/jbm.a.35387.

99. Kołodziejska, B.; Kaflak, A.; Kolmas, J. Biologically Inspired Collagen/Apatite Composite Biomaterials for Potential Use in Bone Tissue Regeneration-A Review. Materials 2020, 13, https://doi.org/10.3390/ma13071748.

100. Elango, J.; Zhang, J.; Bao, B.; Palaniyandi, K.; Wang, S.; Wenhui, W.; Robinson, J.S. Rheological, Biocompatibility and Osteogenesis Assessment of Fish Collagen Scaffold for Bone Tissue Engineering. International Journal of Biological Macromolecules 2016, 91, 51-59, https://doi.org/10.1016/j.ijbiomac.2016.05.067.

101. Liu, Y.; Gu, J.; Fan, D. Fabrication of High-Strength and Porous Hybrid Scaffolds Based on NanoHydroxyapatite and Human-Like Collagen for Bone Tissue Regeneration. Polymers 2020, 12, https://doi.org/10.3390/polym12010061.

102. Bermueller, C.; Schwarz, S.; Elsaesser, A. F.; Sewing, J.; Baur, N.; von Bomhard, A.; Scheithauer, M.; Notbohm, H.; Rotter, N. Marine Collagen Scaffolds for Nasal Cartilage Repair: Prevention of Nasal Septal Perforations in a New Orthotopic Rat Model Using Tissue Engineering Techniques. Tissue Engineering Part A 2013, 19, 2201-2214, https://doi.org/10.1089/ten.tea.2012.0650.

103. Ohnishi, A.; Osaki, T.; Matahira, Y.; Tsuka, T.; Imagawa, T.; Okamoto, Y.; Minami, S. Evaluation of the Chondroprotective Effects of Glucosamine and Fish Collagen Peptide on a Rabbit ACLT Model Using Serum Biomarkers. Journal of Veterinary Medical Science 2012, 75, 421-429, https://doi.org/10.1292/jvms.12-0240.

104. Hsu, H.-H.; Uemura, T.; Yamaguchi, I.; Ikoma, T.; Tanaka, J. Chondrogenic Differentiation of Human Mesenchymal Stem Cells on Fish Scale Collagen. Journal of Bioscience and Bioengineering 2016, 122, 219-225, https://doi.org/10.1016/j.jbiosc.2016.01.001

105. Pustlauk, W.; Paul, B.; Gelinsky, M.; Bernhardt, A. Jellyfish Collagen and Alginate: Combined Marine Materials for Superior Chondrogenesis of HMSC. Materials Science and Engineering: C 2016, 64, 190198, https://doi.org/10.1016/j.msec.2016.03.081.

106. Diogo, G.S.; Carneiro, F.; Freitas-Ribeiro, S.; Sotelo, C.G.; Pérez-Martín, R.I.; Pirraco, R.P.; Reis, R.L.; Silva, T.H. Prionace Glauca Skin Collagen Bioengineered Constructs as a Promising Approach to Trigger Cartilage Regeneration. Materials Science and Engineering: $C \quad$ 2020, 120 , https://doi.org/10.1016/j.msec.2020.111587.

107. Rodrigues, S.C.; Salgado, C.L.; Sahu, A.; Garcia, M.P.; Fernandes, M.H.; Monteiro, F.J. Preparation and Characterization of Collagen-Nanohydroxyapatite Biocomposite Scaffolds by Cryogelation Method for Bone Tissue Engineering Applications. Journal of Biomedical Materials Research Part A 2013, 101A, 10801094, https://doi.org/10.1002/jbm.a.34394. 
108. Raabe, O.; Reich, C.; Wenisch, S.; Hild, A.; Burg-Roderfeld, M.; Siebert, H.-C.; Arnhold, S. Hydrolyzed Fish Collagen Induced Chondrogenic Differentiation of Equine Adipose Tissue-Derived Stromal Cells. Histochemistry and Cell Biology 2010, 134, 545-554, https://doi.org/10.1007/s00418-010-0760-4.

109. Szychlinska, M.A.; Calabrese, G.; Ravalli, S.; Dolcimascolo, A.; Castrogiovanni, P.; Fabbi, C.; Puglisi, C.; Lauretta, G.; Di Rosa, M.; Castorina, A.; Parenti, R.; Musumeci, G. Evaluation of a Cell-Free Collagen Type I-Based Scaffold for Articular Cartilage Regeneration in an Orthotopic Rat Model. Materials 2020, 13, https://doi.org/10.3390/ma13102369.

110. Zhang, Y.; Cao, Y.; Zhao, H.; Zhang, L.; Ni, T.; Liu, Y.; An, Z.; Liu, M.; Pei, R. An Injectable BMSC-Laden Enzyme-Catalyzed Crosslinking Collagen-Hyaluronic Acid Hydrogel for Cartilage Repair and Regeneration. J. Mater. Chem. B 2020, 8, 4237-4244, https://doi.org/10.1039/D0TB00291G.

111. Essen, T.H.van; Lin, C.C.; Hussain, A.K.; Maas, S.; Lai, H.J.; Linnartz, H.; Berg, T.J.T.P.van den; Salvatori, D.C.F.; Luyten, G.P.M.; Jager, M.J. A Fish Scale-Derived Collagen Matrix as Artificial Cornea in Rats: Properties and Potential. Invest. Ophthalmol. Vis. Sci 2013, 54, 3224-3233, https://doi.org/10.1167/iovs.1311799.

112. Tang, J.; Saito, T. Biocompatibility of Novel Type I Collagen Purified from Tilapia Fish Scale: An In Vitro Comparative Study. BioMed Research International 2015, 2015, 1-8, https://doi.org/10.1155/2015/139476.

113. Liu, C.; Sun, J. Hydrolyzed Tilapia Fish Collagen Induces Osteogenic Differentiation of Human Periodontal Ligament Cells. Biomed. Mater 2015, 10, https://doi.org/10.1088/1748-6041/10/6/065020.

114. Zhou, T.; Liu, X.; Sui, B.; Liu, C.; Mo, X.; Sun, J. Development of Fish Collagen/Bioactive Glass/Chitosan Composite Nanofibers as a GTR/GBR Membrane for Inducing Periodontal Tissue Regeneration. Biomed. Mater 2017b, 12,. https://doi.org/10.1088/1748-605X/aa7b55.

115. Elango, J.; Selvaganapathy, P. R.; Lazzari, G.; Bao, B.; Wenhui, W. Biomimetic Collagen-Sodium AlginateTitanium Oxide (TiO2) 3D Matrix Supports Differentiated Periodontal Ligament Fibroblasts Growth for Periodontal Tissue Regeneration. International Journal of Biological Macromolecules 2020, 163, 9-18, https://doi.org/10.1016/j.ijbiomac.2020.06.173.

116. Pankajakshan, D.; Voytik-Harbin, S.L.; Nör, J.E.; Bottino, M. C. Injectable Highly Tunable Oligomeric Collagen Matrices for Dental Tissue Regeneration. ACS Appl. Bio Mater 2020, 3, 859-868, https://doi.org/10.1021/acsabm.9b00944.

117. Allan, B.; Ruan, R.; Landao-Bassonga, E.; Gillman, N.; Wang, T.; Gao, J.; Ruan, Y.; Xu, Y.; Lee, C.; Goonewardene, M.; Zheng, M. Collagen Membrane for Guided Bone Regeneration in Dental and Orthopedic Applications. Tissue Engineering Part A 2020, https://doi.org/10.1089/ten.tea.2020.0140.

118. Bellucci, D.; Salvatori, R.; Giannatiempo, J.; Anesi, A.; Bortolini, S.; Cannillo, V. A New Bioactive Glass/Collagen Hybrid Composite for Applications in Dentistry. Materials 2019, 12, https://doi.org/10.3390/ma12132079.

119. Prashant, K.B.; Dandge, P.B. Isolation, Characterization and Valorizable Applications of Fish Scale Collagen in Food and Agriculture Industries. Biocatalysis and Agricultural Biotechnology 2016, 7, 234-240, https://doi.org/10.1016/j.bcab.2016.06.010.

120. Ruozi, B.; Parma, B.; Croce, M.A.; Tosi, G.; Bondioli, L.; Vismara, S.; Forni, F.; Vandelli, M.A. CollagenBased Modified Membranes for Tissue Engineering: Influence of Type and Molecular Weight of GAGs on Cell Proliferation. International Journal of Pharmaceutics 2009, 378, 108-115, https://doi.org/10.1016/j.ijpharm.2009.05.049.

121. Sixma, J.J.; Zanten, G.H.van; Huizinga, E.G.; Plas, R.M.van der; Verkley, M.; Wu, Y.-P.; Gros, P.; Groot, P.G.D. Platelet Adhesion to Collagen: An Update. Thromb Haemost 1997, 78, 434-438, https://doi.org/10.1055/s-0038-1657565.

122. Cheng, X.; Shao, Z.; Li, C.; Yu, L.; Raja, M.A.; Liu, C. Isolation, Characterization and Evaluation of Collagen from Jellyfish Rhopilema Esculentum Kishinouye for Use in Hemostatic Applications. PLoS One 2017, 12, https://doi.org/10.1371/journal.pone.0169731.

123. Fang, Y.; Zhang, T.; Song, Y.; Sun, W. Assessment of Various Crosslinking Agents on Collagen/Chitosan Scaffolds for Myocardial Tissue Engineering. Biomed. Mater 2020, 15, https://doi.org/10.1088/1748$605 \mathrm{X} / \mathrm{ab} 452 \mathrm{~d}$.

124. Walimbe, T.; Calve, S.; Panitch, A.; Sivasankar, M.P. Incorporation of Types I and III Collagen in Tunable Hyaluronan Hydrogels for Vocal Fold Tissue Engineering. Acta Biomaterialia 2019, 87, 97-107, https://doi.org/10.1016/j.actbio.2019.01.058

125. Ionescu, O.; Ciocilteu, M.V.; Manda, C.V.; Neacsu, I.A.; Ficai, A.; Amzoiu, E.; Stiolica, A.T.; Croitoru, O.; Neamtu, J. Bone - Graft Delivery Systems of Type PLGA-gentamicin and Collagen - hydroxyapatite gentamicine. Materiale Plastice 2019, 56, 534-537.

126. Neacsu, I.A.; Arsenie, L.V.; Trusca, R.; Ardelean, I.L.; Mihailescu, N.; Mihailescu, I.N.; Ristoscu, C.; Bleotu, C.; Ficai, A.; Andronescu, E. Biomimetic Collagen/Zn2+-Substituted Calcium Phosphate Composite Coatings on Titanium Substrates as Prospective Bioactive Layer for Implants: A Comparative Study Spin Coating vs. MAPLE. Nanomaterials 2019, 9, https://doi.org/10.3390/nano9050692.

127. Vladu, A.F.; Marin, S.; Neacsu, I.A.; Trusca, R.D.; Kaya, M.G.A.; Kaya, D.A.; Popa, A.M.; Poiana, C.; Cristescu, I.; Orlov, C., et al. Spongious Fillers Based On Collagen - Hydroxyapatite - Eugenol Acetate With 
Therapeutic Potential In Bone Cancer. Farmacia 2020, 68, 313-321, https://doi.org/10.31925/farmacia.2020.2.17.

128. Li, J.; Wang, M.; Qiao, Y.; Tian, Y.; Liu, J.; Qin, S.; Wu, W. Extraction and Characterization of Type I Collagen from Skin of Tilapia (Oreochromis Niloticus) and Its Potential Application in Biomedical Scaffold Material for Tissue Engineering. Process Biochemistry 2018, 74, 156-163, https://doi.org/10.1016/j.procbio.2018.07.009. 